\title{
The International Financial Integration of China and India*
}

\author{
Philip R. Lane \\ IIIS, Trinity College Dublin and CEPR
}

\author{
Sergio L. Schmukler \\ World Bank
}

\begin{abstract}
Three main features characterize the international financial integration of China and India. First, while only having a small global share of privately-held external assets and liabilities (with the exception of China's FDI liabilities), these countries are large holders of official reserves. Second, their international balance sheets are highly asymmetric: both are "short equity, long debt." Third, China and India have improved their net external positions over the last decade although, based on their income level, neoclassical models would predict them to be net borrowers. Domestic financial developments and policies seem essential in understanding these patterns of integration. These include financial liberalization and exchange rate policies; domestic financial sector policies; and the impact of financial reform on savings and investment rates. Changes in these factors will affect the international financial integration of China and India (through shifts in capital flows and asset/liability holdings) and, consequently, the international financial system.
\end{abstract}

JEL Classification Numbers: F02; F30, F31, F32, F33, F36

Keywords: Financial integration, capital flows, China, India, world economy

World Bank Policy Research Working Paper 4132, February 2007

The Policy Research Working Paper Series disseminates the findings of work in progress to encourage the exchange of ideas about development issues. An objective of the series is to get the findings out quickly, even if the presentations are less than fully polished. The papers carry the names of the authors and should be cited accordingly. The findings, interpretations, and conclusions expressed in this paper are entirely those of the authors. They do not necessarily represent the view of the World Bank, its Executive Directors, or the countries they represent. Policy Research Working Papers are available online at http://econ.worldbank.org.

* This paper is part of a broader project to understand the implications of China's and India's emergence for the world economy. A shorter version of this paper was published as Chapter 4 of the book Dancing with Giants: China, India, and the Global Economy, L. Alan Winters and Shahid Yusuf (eds.), 2007. We thank many colleagues at the IMF and World Bank for interacting with us at the initial stages of this project. For useful comments, we are grateful especially to Bob McCauley and L. Alan Winters, and to Priya Basu, Richard Cooper, Subir Gokarn, Yasheng Huang, Taka Ito, Phil Keefer, Laura Kodres, Aart Kraay, Louis Kuijs, Jong-Wha Lee, Simon Long, Guonan Ma, and T. N. Srinivasan. We also are grateful to participants at presentations held at the World Bank China Office (Beijing), the World Bank headquarters (Washington, DC), the conference "China and Emerging Asia: Reorganizing the Global Economy" (Seoul), the Indian Council for Research on International Economic Relations-World Bank conference "Increased Integration of China and India in the Global Financial System” (Delhi), the Center for Pacific Basin Studies’ 2006 Pacific Basin conference (Federal Reserve Bank of San Francisco), the National University of Singapore SCAPE-IPSWorld Bank workshop (Singapore), and the 2006 IMF-World Bank Annual Meetings (Singapore) for very helpful feedback. Jose Azar, Agustin Benetrix, Francisco Ceballos, Vahagn Galstyan, Niall McInerney, and Maral Shamloo provided excellent research assistance at different stages of the project. We thank the Singapore Institute of Policy Studies; Institute for International Integration Studies; the World Bank Irish Trust Fund; and the World Bank Research Department, East Asia Region and South Asia Region, for financial support. Authors’ Email Addresses: plane@tcd.ie, sschmukler@worldbank.org. 


\section{The International Financial Integration of China and India Paper Outline}

I. Introduction

II. The International Financial Integration of China and India: Basic Stylized Facts

III. The Domestic Financial Sector and the International Financial Integration

IV. Impact on Global Financial System

IV.a. How Important Are China and India as a Destination for External Capital?

IV.b. How Important Are China and India as International Investors?

IV.c. What Is the Contribution of China and India to Global Imbalances?

IV.d. Do China and India Pose Additional Global Risks?

V. Conclusions

Appendix I. Evolution of China's Domestic Financial Sector

Appendix II. Evolution of India's Domestic Financial Sector 


\section{Introduction}

The goal of this paper is to assess how the increasing economic prominence of China and India is reshaping the international financial system. China and India have grown rapidly in the last decade, at average annual growth rates of 9.1 percent and 6.1 percent, respectively, and they are expected to continue their fast growth in the years to come. For example, Winters and Yusuf (2007) project that China and India are expected to grow at annual rates of 6.6 and 5.5 percent, respectively, between 2005 and 2020, while the world economy is expected to grow at 3.1 percent per year during the same period, resulting in projected shares of world GDP for China and India of 8.2 and 2.4 percent in 2020. Their exports and imports of merchandise and services have also grown substantially in recent years. ${ }^{1}$ This economic performance, combined with the openness of their economies, makes China and India crucial players in the world economy. ${ }^{2}$

China and India have also become increasingly prominent in the international financial system. Both countries have gradually adopted policies that are more market oriented and open to the flow of capital across their borders. Although their financial systems still remain restricted, China and India have received significant capital inflows in recent years. Moreover, both China and India have become key outward investors. In particular, China is the world's largest holder of foreign reserves, reaching 853.7 billion U.S. dollars at the end of February 2006. India's reserves are also very high, standing at 139.5 billion dollars in mid-January 2006. Although at a much smaller scale, China and India have also recently started to invest in the private sectors of other countries: the most well-known example is the purchase of the PC business unit of IBM by the Chinese company Lenovo. $^{3}$

To analyze the implications of the emergence of China and India for the global financial system, we consider several dimensions of their international financial integration: net foreign asset positions, gross holdings of foreign assets and foreign liabilities, and the equity-debt mix on international balance sheets. We also analyze the importance of domestic developments and policies related to their domestic financial systems for both the current configuration of their external assets and liabilities and the dynamics of the international financial integration of China and India. ${ }^{4}$ We thus discuss the effects of three different interrelated domestic factors in each economy: (i) financial liberalization and exchange rate/monetary policies; (ii) the evolution of the financial sector; and (iii) the impact of financial reform on savings and investment rates. Finally, we assess the current international financial impact of these countries and probe how their increasing

\footnotetext{
${ }^{1}$ Over 1985-2004, the trade/GDP ratio for China increased from 24.1 percent to 69.4 percent, while the ratio for India grew from 13.2 percent to 39.9 percent. By 2004, China accounted for 6.3 percent of global trade, with India taking a 0.9 percent share. (As is the case throughout this paper, these calculations do not take into account the revision to Chinese GDP data that was announced at the end of 2005.)

${ }^{2}$ For instance, UNCTAD's 2005 Trade and Development Report argues that strong demand, especially from China and India, is the main factor behind the increase in commodity prices (including oil) since 2002.

${ }^{3}$ See Huang (2006) for an analysis of this transaction.

${ }^{4}$ In the other direction, it is clear that international financial integration fundamentally influences the functioning of the domestic financial system. That relation, however, is not the focus of this paper.
} 
weight in the international financial system will affect the rest of the world over the medium term.

Three salient features emerge from the analysis of China's and India's international financial integration. First, regarding size, China and India still have only a small global share of privately-held external assets and liabilities (with the exception of China's foreign direct investment [FDI] liabilities). Second, in terms of composition, these countries' international financial integration is highly asymmetric. On the asset side, they both hold mostly low-yield foreign reserves: by 2004, these countries accounted for 20 percent of global official reserves. Higher-return equity instruments feature more prominently on the liability side, primarily taking the form of FDI in China and portfolio equity liabilities in India. Third, although neoclassical models would predict these countries to be net borrowers in the international financial system (given their economic development), over the last decade both China and India have reversed their large net liability positions, with China even becoming a net creditor. Their debtor and creditor positions in the world economy are small. We argue that domestic financial developments and policies, including the exchange rate regime, are essential factors in explaining these patterns of integration with the international financial system and in projecting future integration.

Those three characteristics of China's and India's current engagement with the global financial system have offered these countries some important benefits in recent years. Accumulating reserves has insured them against the risk of international financial crises and has enabled these countries to maintain stable exchange rates. FDI inflows to China have contributed to technology transfer and portfolio equity inflows to India have facilitated the rapid expansion of its stock market, while the domestic financial sectors of both countries have been mostly insulated from the potentially destabilizing impact of greater cross-border debt flows. Finally, improving net foreign asset positions may have been a prudent response in the wake of India's crisis in the early 1990s and, more recently, the 1997-1998 Asian financial crisis.

The current strategy nonetheless entails considerable opportunity costs in terms of the pattern of net resource flows, the "long debt, short equity" financial profile, the constraints on domestic monetary autonomy, and the insulation of the domestic banking sector from external competitive pressures. In particular, the benefits of reserve accumulation come with a cost due to the return differential; on average, these countries pay more on their liabilities than they earn on their assets. Moreover, as our analysis will highlight, domestic financial development alters the current strategy's cost-benefit ratio, because the rationale for financial protectionism declines and the potential gain from a more liberal capital account regime increases.

Looking to the future is a difficult task, and projections on the evolution of China's and India's international financial positions are conditional on changes in their domestic financial systems, among other things. Nevertheless, we project that further progress in domestic financial reform and liberalization of the capital account will lead to a restructuring of these countries' international balance sheets. In particular, further 
financial liberalization will widen opportunities for foreign investment and expand the international investment alternatives for domestic residents, with the accumulation of external assets and liabilities by the private sectors in these countries likely to grow. With these changes, we may expect to see a diminution in the compositional asymmetries of external liabilities, with a greater dispersion of inflows among the FDI, portfolio equity, and debt categories. On the asset side, there should be a marked increase in the scale of acquisition of non-reserve foreign assets. With the projected increase in their shares in world gross domestic product (GDP), China and India are set to become major international investing nations.

Although projections about net balances are subject to much uncertainty, institutional reforms and further domestic financial development would put pressure on the emergence of significant current account deficits in both countries in the medium or long term, all else being equal. Accordingly, if taken together with a possible deceleration in their rate of reserve accumulation, the roles of China and India in the global distribution of external imbalances could undergo a substantial shift in the coming years. These changes will have significant implications for other participants in the international financial system.

The analysis in this paper builds on several strands of the existing literature. A number of recent contributions have highlighted the importance of domestic financial reform for the evolution of these countries' external positions. ${ }^{5}$ The roles of China and India in the international financial system have been much debated, with opinions divided between those who consider the current role of these countries (together with other emerging Asian economies) as large-scale purchasers of reserve securities to be essentially stable in the medium to long run and those who believe that the current configuration is a more transitory phenomenon. ${ }^{6}$

Relative to the existing literature, we make a number of contributions. First, we provide a side-by-side examination of China's and India's current degree of international financial integration, with a focus on the level and composition of their international balance sheets. Although we put these countries together in the analysis because of their size and growing economic importance, many differences remain and are highlighted in the paper. Second, we provide a comparative account of the development of their domestic financial sectors, and we show how distinct policies in the two countries help explain differences in their external capital structures. ${ }^{7}$ Third, we conduct a forward-looking assessment of how future reforms in their domestic financial sectors will affect the evolution of

\footnotetext{
${ }^{5}$ On China, see among others Blanchard and Giavazzi (2005), Chamon and Prasad (2005), Lim, Spence and Hausmann (2005), Goodfriend and Prasad (2006), Ju and Wei (2006), and Prasad and Rajan (2006). On India, see among others Kletzer (2005) and Patnaik and Shah (2006b).

${ }^{6}$ Dooley, Folkerts-Landau, and Garber (2003) famously dubbed this configuration the "Bretton Woods II" system; Caballero, Farhi, and Gourinchas (2006) provide theoretical support. Although this hypothesis has a broad appeal in explaining the stylized facts of recent imbalances, it remains highly controversial. Other authors, such as Aizenman and Lee (2005), Eichengreen (2004), Goldstein and Lardy (2005), and Obstfeld and Rogoff (2005) provide broad-ranging critiques.

${ }^{7}$ The analysis here is partly based on Bai (2006), Kuijs (2006), Li (2006), Mishra (2006), Patnaik and Shah (2006a), and Zhao (2006).
} 
international balance sheets, with an emphasis on highlighting the broader impact on the international financial system.

The rest of the paper is organized as follows. In Section II, we document the basic stylized facts of the international financial integration of China and India. Section III briefly links these facts to the developments in the countries' domestic financial sectors. (A more detailed account of the development in each financial sector is provided in Appendices I and II.) Section IV analyzes the impact of their international integration on the global financial system. In particular, we discuss: (i) China and India as a destination for external capital; (ii) China and India as international investors; (iii) the contribution of China and India to global imbalances; (iv) whether China and India pose additional global risks. Section V offers some concluding remarks.

\section{The International Financial Integration of China and India: Basic Stylized Facts}

To document the major trends in China's and India's international financial integration, we study the international balance sheets of each country. ${ }^{8}$ As mentioned above, we analyze: net foreign asset positions; gross holdings of foreign assets and foreign liabilities; and the equity-debt mix in their international balance sheets. Our focus on the international balance sheets has an advantage over capital flows, since the accumulated holdings of external assets and liabilities is the most informative indicator of the extent of international financial integration (Lane and Milesi-Ferretti 2006). ${ }^{9}$ Moreover, they provide a reasonable measure of international portfolios, where they stand and how they might shift, and help to compare stock positions with the evolution of capital flows (with flows responding to stock adjustments). In some places we also discuss recent patterns in capital flows, especially where these patterns signal that the current accumulated positions are undergoing some structural changes toward new portfolio balances.

We start with Figure 1, which plots the evolution of the net foreign asset positions of China and India from 1985 to 2004. The figure shows that both countries have followed a similar path - accumulating net liabilities until the mid 1990s but subsequently experiencing a sustained improvement in net foreign asset position. By 2004, China was a net creditor at 8 percent of GDP, whereas Indian net external liabilities had declined from a peak of 35 percent of GDP in 1992 to 10 percent of GDP in 2004. Figure 1 also shows that the net foreign asset positions of other East Asian countries also have improved in the wake of the 1997-98 financial crisis, while the net positions of the G7, Eastern Europe, and Latin America have deteriorated. According to the IMF's World Economic Outlook database, since 2004, China's current account surplus has continued to increase, reaching 7.2 percent in 2005 and projected at 7.2 percent for 2006-07,

\footnotetext{
${ }^{8}$ Lane (2006) provides more details concerning the historical evolution of the international balance sheets of China and India.

${ }^{9}$ The international balance sheets cumulates capital inflows and outflows and, at the same time, takes into account the impact of valuation changes driven by capital gains and losses on asset and liability positions. The size of cross-border holdings highlights the relative importance of China and India in global crossborder portfolios. The level of foreign assets also determines the level of their exposure to external financial shocks, while the level of foreign liabilities measures the vulnerability of foreign investors to domestic shocks.
} 
strengthening their creditor position. In contrast, the Indian current account balance has returned to negative territory with a deficit of 1.5 percent in 2005 and projected deficits of 2.1 and 2.7 percent for 2006 and 2007, respectively, thus deepening their debtor position.

Compared with other developing countries, Figure 2 shows that China and India had at the end of 2004 net foreign asset positions that were less negative than is typically the case for countries at a similar level of development. This remains true today. Although some developing countries have more positive net positions, those typically are resourcerich economies.

In global terms, the imbalances of China and India are relatively small, as illustrated in Table 1. At the end of 2004, the Chinese creditor position amounted to only 7.4 percent of the level of Japanese net foreign assets (Japan is the world's largest creditor nation), whereas Indian net liabilities were only 2.8 percent of U.S. net external liabilities (the U.S. is the world's largest debtor nation). Scaled differently, China's net creditor position of 131 billion dollars at the end of 2004 amounted to only 5 percent of the U.S. negative external position of $\$ 2.65$ trillion. ${ }^{10}$ However it is increasingly important on a flow basis: its projected 2006 current account surplus of $\$ 184$ billion amounts to more than 20 percent of the projected U.S. current account deficit of $\$ 869$ billion (IMF, World Economic Outlook database).

Underlying these net positions is a significant increase in the scale of China's and India's international balance sheets. Figure 3 shows the sum of foreign assets and liabilities (divided by GDP). This indicator of international financial integration has increased sharply for both countries in recent years, although the levels are not high when compared with other regions, as shown in the lower panels of Figure 3. Whereas the growth in cross-border holdings is substantial, Figure 4 shows that the relative pace of financial integration has lagged behind the expansion in trade integration and the growth in China's and India's share in global GDP. ${ }^{11}$

There are significant asymmetries in the composition of the underlying stocks of gross foreign assets and liabilities. Table 2 a shows the composition of foreign assets and liabilities for China and India. On the assets side, the equity position (portfolio and FDI) is relatively minor for both countries, with a predominant role for external reserve assets that amount to 31.8 percent of GDP for China and 18.3 percent of GDP for India at the end of 2004. On the liabilities side, the table also shows some important differences between the two countries. In particular, equity liabilities primarily take the form of FDI in China, whereas portfolio equity liabilities are predominant for India. External debt comprises less than one third of Chinese liabilities but more than one half in the Indian

\footnotetext{
${ }^{10}$ These calculations are based on data drawn from Lane and Milesi-Ferretti (2006). In recent years, the major oil exporters plus other Asian economies have also run substantial current account surpluses.

11 See Lane and Milesi-Ferretti (2002) on the use of this measure as a volume-based indicator of international financial integration. The comparison of this measure of financial integration with the typical measure of trade integration shows interesting differences across countries. For example, Lane and MilesiFerretti (2006) find that, relative to the pace of trade integration, financial integration has proceeded more rapidly among the advanced nations than for the aggregate of developing countries.
} 
case. Figure 5 shows the evolution of the composition of assets and liabilities and compares them across regions.

Table $2 \mathrm{~b}$ considers the net positions in each asset category at the end of 2004 - both China and India are "long in debt, short in equity:" these countries have positive net debt positions and negative net equity positions. As observed by Lane and Milesi-Ferretti (2006), this is currently a common pattern for developing countries. However, the scale of the asymmetry is striking, especially in China's case.

Figure 6 shows China's and India's relative importance of the different components of the international balance sheets. Relative to other countries, one of the most notable features of China and India is their low levels of non-reserve foreign assets (also discussed in Lane 2006). According to the data compiled by Lane and Milesi-Ferretti (2006), China's foreign portfolio and FDI assets amounted to $\$ 5.7$ billion and $\$ 35.8$ billion respectively at the end of 2004, while the figures for India were $\$ 0.95$ billion and $\$ 9.6$ billion, respectively. Relative to global stocks of foreign portfolio equity and FDI assets ( $\$ 8.98$ trillion and $\$ 12.55$ trillion, respectively), these correspond to global shares of 0.06 percent (China) and 0.01 percent (India) in terms of foreign portfolio equity assets and 0.29 and 0.08 percent in terms of FDI assets. ${ }^{12}$ As a benchmark, their shares in global dollar GDP are 4.7 percent and 1.7 percent, respectively, whereas they hold 16.0 percent and 3.3 percent of world reserves.

The relative insignificance of India and China as outward direct investors is also highlighted in UNCTAD's World Investment Report 2005, which ranks India and China as 54th and 72nd out of 132 countries in terms of outward FDI over 2002-2004. This report also remarks that China had only five firms and India only one firm in the top fifty transnational corporations from developing countries over that period. While there is evidence of an increase in outward FDI during 2005 and the first part of 2006, it is clear that this is from a very low base.

Regarding global impact, Figure 6 shows that by the end of 2004 the FDI liabilities of China represented 4.1 percent of global FDI liabilities. Although this is broadly in line with China's share in world GDP (in dollars), global shares are much lower for the other non-reserve elements of the international balance sheet. In portfolio terms, China and India are "underweight" both as destinations for international investors and as investors in non-reserve foreign assets (Lane 2006).

A salient characteristic in the bilateral patterns in FDI is the predominance of Hong Kong (China) and Mauritius as sources of FDI for China and India respectively (see Table 3a). This reflects the importance of these offshore centers as an entry point for direct investment into China and India. In fact, for China, more than fifty percent of FDI comes from offshore centers. As discussed in the next section, this also likely reflects roundtripping activities, by which domestic residents route investment through offshore entities in order to avail of the tax incentives and other advantages that are provided to foreign

\footnotetext{
${ }^{12}$ It would be interesting to analyze a similar figure but using both foreign and domestically held assets as a benchmark. Unfortunately, good-quality data on the latter are not available.
} 
direct investors. The British Virgin Islands in the case of China also play a similar role. ${ }^{13}$ Similar to the situation for FDI, a large proportion of portfolio investment is channeled via Hong Kong (China) and Mauritius, as shown in Table 3b. More generally, the geographical investment patterns highlights that much of the investment in China is coming from other Asian economies, whereas it is investors from the advanced economies that are most prominent in India. In part, this disparity reflects the differential impact of geography on FDI versus portfolio investment; it might be attributed to the large ethnic Chinese emigrant communities in Asia that are a natural source of investment flows to China.

To summarize, the current state of the international financial integration of China and India has several striking features. First, their international balance sheets are highly asymmetric - with official reserves dominating the asset side, and equity liabilities highly important for both countries (FDI for China, portfolio equity for India). Second, the absolute level of non-reserve foreign assets is very low. In terms of global impact, these countries' global holdings of foreign assets and liabilities are relatively small, with the important exception of the official reserves category. Third, the net foreign asset positions of these countries are more positive than might be expected for countries at their level of development.

\section{The Domestic Financial Sector and International Financial Integration}

To probe the extent to which the stylized facts above can be explained by developments and policies related to the domestic financial sectors in China and India, we very succinctly summarize the trends in three interrelated aspects of the financial sector: financial liberalization and exchange rate policies, the evolution (and state) of the domestic financial sector, and patterns in savings and investment. A much more detailed, but still brief account is provided in Appendices I and II, complementing the description in this section.

As becomes evident when summarizing their evolution, these factors are fundamentally related to cross-border asset trade and the international balance sheets. This section highlights the sharp changes in the domestic financial sector in each country since the early 1990s, the expected changes in the years to come, and their interaction with the international financial integration. We conduct the analysis by turning to the particular developments in the financial sectors of each country.

\section{III.a. China}

China has adopted a gradualist approach to financial liberalization, including the capital account. During the 1980s and 1990s, the main focus was on promoting inward direct investment flows (that is, FDI), which led to a surge of direct investment in China in the 1990s. Investment by foreigners in China's stock markets has been permitted since 1992 through multiple share classes, but access is still restricted and a heavy overhang of stateowned shares limits its attractiveness. Debt inflows have been especially restricted, as

\footnotetext{
${ }^{13}$ See World Bank (2002) and Xiao (2004).
} 
have been private capital outflows. This has enabled the state to control the domestic banking sector by setting ceilings on interest rates, for example. Table 4 provides a summary of these measures.

China's financial liberalization policies have been linked intrinsically to its exchange rate regime. Since 1995, the renminbi (RMB) has been de facto pegged to the U.S. dollar, albeit with a limited degree of flexibility since the 3 percent revaluation in July 2005. A stable value of the exchange rate has been viewed as a domestic nominal anchor and an instrument to promote trade and FDI. The twin goals of maintaining a stable exchange rate and maintaining an autonomous monetary policy have contributed to the ongoing retention of extensive capital controls.

These policies have had a large impact on China's international balance sheet. The capital account restrictions have encouraged significant round-tripping, as shown in Table 3a, with Hong Kong (China) playing a dominant role in channeling investment into China. Moreover, targeting the exchange rate has had a powerful influence on the composition of China's international balance sheet. On the liabilities side, the scale of private capital inflows (at least until the July 2005 regime switch) can be attributed partly to speculative inflows in anticipation of RMB appreciation (Prasad and Wei 2005). ${ }^{14}$ To avoid currency appreciation, the counterpart of high capital inflows has been the rapid accumulation of external reserves and expansion in monetary aggregates (see Figure 7). In turn, the sustainability of reserves accumulation has been facilitated by interest rate regulation that has kept down the cost of sterilization (Bai 2006).

Turning to the domestic financial sector, China's level of domestic financial market development was low at the start of the reform process in 1978. Gradual liberalization of the sector has been accompanied by a sharp deepening of the financial development indicators in China during the last 15 years, as shown in Figures 8-9.

Regarding the banking sector, Figure 8 shows that bank credit to GDP increased almost twofold and deposits to GDP rose almost threefold between 1991 and 2004, reaching levels much higher than those in India and other relevant benchmark groups (East Asia, Eastern Europe, Latin America, and the G7). In terms of size, credit is as high as in the G7 economies, and deposits are substantially larger than all the other comparators. Despite the apparent financial depth captured by these indicators, the banking sector remains excessively focused on lending to state-owned enterprises, and it does not appear to be an adequate provider of credit to private enterprises and households. An interest rate ceiling also distorts the behavior of banks and limits the attractiveness of banks to domestic and foreign investors (Bai 2006).

With respect to domestic capital markets, the Chinese corporate bond market remains underdeveloped. Although the stock market has undergone significant expansion since 1991 (Figure 9), the large overhang of government-owned shares implies that tradable

\footnotetext{
${ }^{14}$ Prasad and Wei (2005) highlight that unrecorded capital inflows have been growing in recent years, as foreign investors seek to evade limits on their ability to acquire RMB assets in anticipation of future currency appreciation.
} 
shares are only about one-third of total stock market capitalization. In addition, equity pricing is perceived as open to manipulation, with the government regularly intervening in the market in response to political lobbying by the brokerage industry. Furthermore, corporate governance in China remains far from international standards. This contrasts with the focus of the Chinese government on guaranteeing safety for direct investment. The difference in the protection of foreigners' property rights between direct and portfolio investments has made FDI much more attractive than portfolio equity for foreign investors wanting to participate in the Chinese market. ${ }^{15}$

Internal funds have been the main source of investment financing for the Chinese corporate sector. According to Kuijs (2006), enterprises in China saved 20 percent of GDP in 2005. Their level of investment, however, was much higher than that, at 31.3 percent of GDP in 2005. Li (2006), in line with these figures, finds that internal financing for Chinese firms has been 70 percent of total fixed asset investment in $2004 .^{16}$

The high aggregate level of investment in China means that external financing has also been important at more than 10 percent of GDP. The most important supplier of external finance has been the banking sector. Li (2006) estimates that bank loans have accounted for around 20 percent of firm financing, while stock and bond issuance have played a minor role. According to Allen, Qian, and Qian (2005), the average ratio of debt to cash flow has been 5.34 for Chinese firms, much higher than the 2.24 average for their comparison group of countries. The ratio of market capitalization to cash flow in China, moreover, is much lower than in the comparator countries. This is consistent with the dominant role of bank credit as a source of external finance. Allen, Qian, and Qian (2005) also show that other important channels of external financing have been FDI - especially for private sector enterprises - and the state budget for state-owned enterprises.

These features of the domestic financial sector help explain some elements of China's integration into the international financial system. In particular, the problems in the banking system (that is, the concentration of its loan book on state-owned enterprises, the significant number of non-performing loans, and solvency concerns) have limited the willingness of the authorities to allow Chinese banks to raise external funds or act as the broker for the acquisition of foreign assets by domestic entities (Setser 2005). ${ }^{17}$ In addition, the distorted nature of the Chinese stock market means that portfolio equity inflows would have been limited even under a more liberal external account regime. Similarly, the domestic bond market is at a very primitive stage of development, and the

\footnotetext{
${ }^{15}$ This is not to deny that poor protection of intellectual property rights in China means that much of the inward FDI is confined to labor-intensive sectors that do not rely on proprietary technologies.

${ }^{16}$ It is important to acknowledge that retained earnings are also a primary source of investment finance in many developed and developing countries (see, for example, Corbett and Jenkinson 1996). However, the efficiency in deploying internal funds will differ between systems with effective external monitors and those lacking an external disciplinary device to constrain the firms' investment decisions.

${ }^{17}$ An interesting exception is that domestic residents are permitted to hold dollar deposits in domestic banks. In 2001, following a further relaxation, a substantial portion of these dollar deposits were employed to invest in B-shares on the Chinese stock market, denominated in foreign currency. See Zhao (2006) and Ma and McCauley (2002).
} 
capacity of domestic entities to undertake international bond issues remains heavily circumscribed.

The third channel linking the domestic financial system with the international balance sheets is domestic savings and investment, with the net difference in turn determining the current account balance.

The domestic financial system influences savings rates through multiple channels. Regarding the household sector, Chamon and Prasad (2005) point out that the lack of consumer credit means that families must accumulate savings to finance the purchase of consumer durables. Moreover, the underdevelopment of social and private insurance requires households to self-insure by accumulating buffer stocks of savings. ${ }^{18}$

Despite these trends at the household level, Kuijs (2005, 2006) shows that the extraordinarily high aggregate savings rate in China is driven primarily by corporate savings. ${ }^{19}$ The high level of enterprise savings required to finance high levels of investment has been facilitated by a low-dividend policy. In the extreme case of many state-owned enterprises, there are no dividends at all. In some cases, the reluctance to distribute profits reflects uncertainty about ownership structures and the weak state of corporate governance. ${ }^{20}$

In addition to a low dividend policy, two more factors help explain high enterprise saving and investment. The first is the high share of the industry sector in GDP, associated with higher saving and investment because of its capital intensity. The second factor is the rising profits of Chinese enterprises in the last 10 years. These enhanced profits can be explained in part by the increasing importance of private firms and the increased efficiency of state-owned enterprises (Kuijs 2006).

On the investment side, the reliance on self-financing and the lack of accountability to shareholders plausibly push up the investment rate, with corporate insiders pursuing projects that would not pass the return thresholds demanded by commercial sources of external finance. ${ }^{21}$ In addition, for state-owned enterprises, access to directed credit from the banking sector enables these firms to maintain higher investment rates than would

${ }^{18}$ Blanchard and Giavazzi (2005) also emphasize that high household savings in China reflect a strong precautionary motive, in view of the low provision of publicly funded health and education services. Furthermore, Modigliani and Cao (2004) argue that the one-child policy has led to a higher percentage of employment to total population and has also undermined the traditional role of family in providing old-age support, thus increasing household savings.

${ }^{19}$ In 2005, household savings were similar to those of other developing countries. For instance, although the household savings rate in China may have been higher than rates of Organization for Economic Cooperation and Development economies, it was actually lower than in India. The government savings rate is also recorded as relatively high in China.

${ }^{20}$ However, the recently established State Asset Supervision and Administration Commission is seeking to assert greater control of state-owned enterprises, including a demand for greater dividend payments. Naughton (2006) provides an analysis of the political struggle over control and income rights in the stateowned sector.

${ }^{21}$ Moreover, the lack of financial intermediation distorts investment patterns, with young or pre-natal firms starved of finance while mature firms inefficiently deploy excess cash flows. 
otherwise be possible. Furthermore, restrictions on capital outflows mean that enterprise investment largely has been restricted to domestic projects.

In sum, the underdevelopment of the domestic financial system may help to explain the high rates of both savings and investment in China. The net impact on the current account is ambiguous in principle, because financial development could reduce both savings and investment rates. However, the cross-country empirical evidence indicates that domestic financial deepening lowers the savings rate and increases investment. ${ }^{22}$ Especially in combination with an open capital account, it is plausible that higher-quality domestic financial intermediation could place greater downward pressure on savings than investment. In particular, the international capital funneled through domestic banks and domestic financial markets to high-return domestic projects may compensate for a reduction in investment in those inefficient enterprises that are protected by the current financial system. Moreover, a better financial system could stimulate consumption (by providing more credit) and reduce the need for maintaining high savings levels (either for precautionary motives or to finance future consumption).

\section{III.b. India}

India suffered a severe financial crisis in the early 1990s, and that crisis subsequently led to a broad series of reforms. The goal was to spur Indian growth by fostering trade, FDI, and portfolio equity flows while avoiding debt flows that were perceived as potentially destabilizing. In the subsequent years, India has undergone extensive but selective liberalization, summarized in Table 5. Substantial capital controls, however, do remain in place.

The discouragement of external debt has restricted domestic entities' ability to issue bonds on international markets and the entry of foreign investors to the domestic bond market. Moreover, the restrictions on purchases by foreigners in the corporate and government bond markets are much more stringent. Hence, the market for private bonds remains underdeveloped, as shown in Figure 10. The restrictions on external debt are heavily influenced by memories of India's debt crisis in the early 1990s, with the composition of capital inflows subsequently shifting towards a much higher ratio of equity to debt flows.

By contrast, the approach to equity inflows has been much more liberal. Restrictions on FDI inflows have been relaxed progressively, although they still exist and India receives far less direct investment compared with China (Table 2a). The distinctive characteristic of equity flows into India, however, is not the direct investment, but rather the relatively high level of portfolio equity financing. India's broad domestic institutional investor base has aided the entry of foreign institutional investors (FIIs) that are permitted to take partial stakes in equity of quoted Indian enterprises.

Capital outflows also are restricted, although the system is being liberalized (Patnaik and Shah 2006a.) In particular, Indian banks are not permitted to acquire external assets, but

\footnotetext{
${ }^{22}$ See International Monetary Fund (2005).
} 
rather are encouraged to hold government bonds, thereby lowering the cost of financing public deficits. Accordingly, current constraints on asset allocation make official reserves the predominant component of foreign assets. As in China, the de facto exchange rate/monetary regime seeks to maintain a stable value of the rupee against the dollar, which provides a nominal anchor and is viewed as promoting trade and investment. The exchange rate regime has been supported by capital controls, which have allowed some degree of monetary autonomy to be combined with the exchange rate target.

Following the crisis of the early 1990s, India initiated a reform of its financial institutions. There were extensive reforms in the equity markets and the banking sector. As Figures 7, 8, and 9 illustrate, the domestic equity market is much more developed in relative terms than is the banking sector or the bond market. Corporate governance was improved, thus encouraging investment by domestic and foreign minority shareholders. ${ }^{23}$

Successful development of the equity market helps explain the change in the equity-debt mix in the financing of listed Indian firms and the entrance of foreign portfolio investment. There has been a shift from debt to equity in recent years, from a 1.82 debtequity ratio in 1992-93 to a 1.06 ratio in 2004-05 (Patnaik and Shah 2006a). In addition to the development of the equity market, this shift may also be linked to the many restrictions on foreign investors wanting to buy corporate bonds. Although FIIs have been allowed to buy bonds since 1996, there has been a cap of one billion dollars on the total corporate bonds that all FIIs can hold. ${ }^{24}$ To make it more restrictive, this cap was lowered to 0.5 billion dollars in 2004 (see also Table 5).

As mentioned above, the third channel linking the domestic financial system with the international balance sheets is domestic savings and investment. India's current saving rate is similar to that of most other Asian economies (Mishra 2006). Indeed, its household savings rate exceeds the Chinese level. Although corporate saving is on an upward trend, however, it is far below the Chinese level, and government saving is relatively low despite an uptick since 2002. On the investment side, private investment has risen steadily while public investment has been declining since the 1980s. In comparing investment levels in China and India, Mishra (2006) notes that an important difference is that India's sectoral growth pattern is more oriented toward services and is thereby less intensive in physical capital. Still, Kochhar, Kumar, Subramanian, Rajan, and Tokatlidis (2006) notes that the next phase of Indian development may require a higher level of physical investment - an expansion in the manufacturing sector is required to absorb lowskilled labor, and there are significant deficiencies in the quality of public infrastructure.

As in China, it is plausible that further development of India's domestic financial sector may prompt a decline in household and corporate savings rates, as the availability of credit from the financial system increases. Even more strongly than in China, further financial development also may stimulate an expansion in investment, in view of the

\footnotetext{
${ }^{23}$ The Indian market's level of corporate governance scores well in the ranking of the CLSA Asia-Pacific Markets and Asian Corporate Governance Association.

${ }^{24}$ A regular FII can hold up to 30 percent of its portfolio in bonds. There are also "100 percent debt" FIIs, which are allowed to hold only debt securities.
} 
credit constraints faced especially by small- and medium-size enterprises. In addition, financial development accompanied by further capital account liberalization will stimulate a greater level of cross-border asset trade, with the acquisition of foreign assets by domestic households and enterprises and the domestic financial system intermediating international capital flows to domestic entities.

\section{Impact on the Global Financial System}

Keeping in mind the framework set above, this section moves to briefly address a series of issues that have emerged concerning the impact of China and India on the global financial system. These issues are very important and deserve much more attention than the one that can be devoted here. But the discussion in this paper tries to summarize the main points, which can be expanded in further work. We group these issues into four broad questions that have already captured attention and, where relevant, highlight the differential effect of China and India on developed and developing countries.

\section{IV.a. How Important Are China and India as a Destination for External Capital?}

China and India account for only a small share of global external liabilities, with the exception of Chinese FDI liabilities which account for 4.1 percent of global FDI liabilities. In terms of FDI flows, however, China looks rather more important: the country absorbed 7.9 percent of global FDI flows in 2003-04 (India's share was 0.8 percent). These high flows might represent the adjustment to a new portfolio balance, in which China captures a higher share of international investment (more in line with its participation in the world economy) after having a very small weighting in foreign portfolios. $^{25,26}$

With respect to portfolio equity liabilities, Lane (2006) and Figure 6 show that China and India each account for just over 0.5 percent of global portfolio equity liabilities. In terms of flows, China received 1.94 percent of global equity flows during 2003-04, and India received 1.79 percent (Lane 2006). Especially in regard to China, this likely understates its impact on the global distribution of equity flows - because of the poor reputation of the Chinese stock market, overseas entities may prefer to build portfolio equity stakes in "proxy" stock markets that are expected to co-move positively with the Chinese economy (most obviously, the Hong Kong (China) equity market can serve this purpose).

\footnotetext{
${ }^{25}$ It is important to stress that the scale of the FDI inflow into China may be exaggerated. In particular, some proportion of FDI represents round-tripping.

${ }^{26}$ Have the large FDI flows to China been at the expense of other Asian emerging market economies? This question is hard to answer and more research would be welcome. But Eichengreen and Tong (2005) argue that FDI flows into China and other Asian developing countries are complements; they give the example of a Japanese parent company that makes joint investments in an assembly plant in China and component production facilities in Singapore and Malaysia. Mercereau (2005) also investigates the impact of China's emergence on FDI flows to Asia over 1984-2002 and finds little evidence that China's success in attracting FDI has been at the expense of other countries in the region, with the exception of Singapore and Myanmar.
} 
Finally, Lane (2006) records that both Chinese and Indian shares in global external debt liabilities have sharply declined in recent years - by 2004, only 0.65 percent and 0.35 percent, respectively. The decline is especially noteworthy for India, which was a much more important international debtor (in relative terms) in the early 1990 s.

Turning to the future, continued domestic financial reform and external liberalization should produce some evolution in the level and composition of China's and India's external liabilities. As a benchmark, an increasing share of these countries in world GDP and world financial market capitalization should naturally prompt increasing capital inflows to these countries. In addition, we may expect to see some rebalancing in the composition of external liabilities. For China, reform of the domestic banking system and the development of its equity and bond markets may reduce its heavy reliance on FDI inflows as alternative options become more viable. A reduction in the relative importance of FDI also may be supported by moves to limit the generosity of the current incentives offered to foreign direct investors, which would attenuate FDI directly and through its attendant impact on round-tripping activity. ${ }^{27}$ Finally, the expansion of domestic capital markets and reform of the banking system also would allow foreign-owned firms to draw on domestic funding sources.

With regard to India, recent moves to further liberalize the FDI regime may increase the relative importance of FDI inflows. India's ability to attract FDI also depends on more widespread institutional reforms that improve the investment environment for foreign investors and encourage them to channel FDI into the country. The major barrier regarding the liberalization of debt inflows could be that opening up the capital account may threaten the government's ability to finance its large fiscal deficits at a low interest cost. Under these conditions, further liberalization may be delayed until the domestic fiscal situation is reformed.

\section{IV.b. How Important Are China and India as International Investors?}

As shown in Table 2a, China and India are much less important as external investors in equity assets than as holders of equity liabilities. This is especially the case for portfolio equity assets, which by 2004 were only 0.3 percent and 0.1 percent of GDP for China and India respectively. Relative to portfolio equity assets, FDI assets in 2004 were much larger - but remain small at 1.9 percent and 1.3 percent of GDP respectively. In terms of non-reserve foreign debt assets, China had a much larger position in 2004 than did India (13.3 percent versus 2.6 percent of GDP). Nevertheless, even the China position is small in global terms, representing just 0.6 percent of global non-reserve foreign debt assets in 2004, as shown in Lane (2006) and Figure 6.

\footnotetext{
${ }^{27}$ While current policy is strongly pro-FDI, one reason to believe that FDI incentives could be scaled back is provided by the increasing political concerns about excessive FDI inflows. At one level, this relates to the demands of farmers whose land has been appropriated to provide industrial sites for direct investors and others (mainly local real estate developers). At another level, domestic firms that compete with foreign direct investors complain about the favorable treatment accorded to the external investors.
} 
In view of the relatively low levels of foreign equity assets and non-reserve foreign debt assets, the foreign assets of China and India are highly concentrated in official reserves, which respectively represent 67 percent and 82 percent of their total foreign asset holdings. As noted in earlier, these countries rank highly in the global distribution of official reserves - at the end of 2004 China and India were second and sixth, respectively, and together accounted for about 20 percent of global reserve holdings.

At the economic level, the rapid pace of reserve accumulation can be interpreted as the byproduct of a development strategy that seeks to promote export-led growth by suppressing appreciation of the nominal exchange rate. For the rest of the world, this has represented a beneficial terms of trade shock, with the increase in manufacturing exports from China leading to a reduction in relative prices and helping to moderate global inflation. For suppliers of inputs to China, the increase in export activity has generated an increase in demand, aiding producers of components in other Asian countries and commodity producers around the world.

On the financial front, the high level of reserves acts as a subsidy that lowers the cost of external finance for the issuers of reserve assets - primarily, the United States. In turn, this helps to keep interest rates lower than otherwise in these economies. For example, a careful empirical study by Warnock and Warnock (2006) estimates that the foreign official flows from East Asia kept U.S. interest rates about 60 basis points below normal levels during 2004-05. This also feeds into higher asset and real estate prices and a reduction in the domestic savings rate, helping explain the large U.S. current account deficit. Regarding the impact on other developing countries, the low global interest rates associated with high reserve holdings also have translated into a compression of spreads on emerging market debt, with the "search for yield" raising the attractiveness of emerging market destinations to international investors (IMF 2006).

There are several reasons to believe that the pace of reserve accumulation will start to decelerate. First, the accumulation of reserves comes at a significant opportunity cost in terms of alternative uses for these funds. For instance, Summers (2006) estimates that the opportunity costs for the world's 10 largest reserve holders amount to 1.85 percent of GDP; Rodrik (2006b) calculates that the cost is near 1 percent of GDP for developing countries taken as a whole. ${ }^{28}$ Because these countries comfortably exceed the reserve levels that are required to cover imports and debt obligations, the opportunity cost may be high relative to the insurance gains from building up reserves as a precaution against financial risks. Second, to the extent that inflows are not sterilized, the increase in domestic liquidity (shown in Figure 7) associated with reserve accumulation threatens the possibility of an asset and real estate price boom and misdirected lending in the domestic economy. Third, it is increasingly appreciated in China that rebalancing output growth toward expanding domestic consumption is desirable to raise living standards even faster and avoid the external protectionist pressures that have been building up in Europe and the United States. Fourth, the move to a more flexible exchange rate system might reduce

\footnotetext{
${ }^{28}$ As an illustration, Summers (2006) assumes that these countries could earn a 6 percent social return on domestic investments; Rodrik (2006b) compares the yield on reserves to the borrowing costs faced by these countries.
} 
the pressure on the monetary authority to intervene in the foreign exchange market in order to maintain a de-facto fixed currency peg.

A slowing of reserve accumulation would have several ramifications. The removal of the interest rate subsidy would raise the cost of capital for the primary issuers of reserve assets. In turn, depending on the policy response, this might contribute to a reversal in global liquidity conditions, which might also adversely affect the supply of capital to emerging market economies. However, the full impact on the international financial system of changes in reserve accumulation is difficult to estimate and depends on the other changes that occur along with the deceleration in reserve accumulation, the external net positions, and their contribution to global imbalances. For example, looking only at reserves does not take into account the amount of capital absorbed by these countries from the international financial system and how that affects global returns. We come back to these points below, in this section and the next one.

To mitigate the opportunity cost of reserve accumulation, countries also may decide to redirect excess reserves toward a more diversified portfolio of international financial assets, which might include the liberalization of controls on outward investment by other domestic entities. ${ }^{29}$ For instance, Genberg, McCauley, Park, and Persaud (2005) support the creation of an Asian investment corporation that would pool some of the reserves held by Asian central banks and manage them on a commercial basis, investing in a broader set of assets with varying risk, maturity, and liquidity characteristics. In related fashion, Prasad and Rajan (2005) have proposed a mechanism by which closed-end mutual funds would issue shares in domestic currency, use the proceeds to purchase foreign exchange reserves from the central bank, and then invest the proceeds abroad. In this way, external reserves would be redirected to a more diversified portfolio and domestic residents would gain access to foreign investment opportunities in a controlled fashion. Finally, Summers (2006) suggests that international financial institutions may have a role to play in establishing a global investment fund that would provide a vehicle for the reallocation of excess reserves held by developing countries. ${ }^{30}$

The different strategies for reserve deceleration have varying implications for the rest of the world. First, to the extent that reserves are reallocated toward other foreign assets, this would have a positive impact on those economies that would benefit from the shift away from the concentration on the reserve assets supplied by a small number of countries toward a more diversified international portfolio. The capacity of emerging market economies to benefit from such a move (especially those in Asia) depends on the policy response. At a domestic level, those economies that made the most progress in

\footnotetext{
${ }^{29}$ Indeed, some redeployment of reserves has occurred already. For instance, China transferred $\$ 60$ billion in reserves in 2004-05 to increase the capital base of several state-owned banks. See also the discussion in European Central Bank (2006).

${ }^{30}$ A global fund may be superior to a regional fund to the extent that Asia may face common shocks such that all countries in the region may simultaneously wish to draw down assets.
} 
developing domestic capital markets and providing an institutional environment that is attractive to direct investors would benefit the most. ${ }^{31}$

Second, a slowdown in reserve accumulation associated with a policy package that promotes increased domestic absorption (for example, through higher domestic consumption in China and higher investment in India) and a reorientation away from export-led growth would have other spillover effects on the rest of the world economy. In effect, it would increase the overall cost of capital for the world economy. But it is important in this case not to overstate the initial impact of a deterioration in the current account balances of these countries because they hold small current positions in the global distribution of external imbalances. However, it is possible to construct scenarios in which these countries become significant net capital importers, as their share of world GDP increases and if their medium-term current account deficits settle down in the 2 percent to 5 percent range.

Third, if a shift in reserves accumulation is associated with a shift in exchange rate policy, a move toward greater currency flexibility also would have spillover effects on other countries. If this shift in exchange rate policy generates less inflows and less reserve accumulation, the effect on the cost of capital in other countries is difficult to predict: it would depend on how the inflows previously going to these countries become allocated elsewhere, relative to how reserves were invested. In addition, the effective Asian "dollar bloc" that has been formed by individual Asian economies each tracking the U.S. dollar would be weakened by such a move. In its place, and political conditions permitting, smaller Asian economies might move to an exchange rate regime that sought to target a currency basket weighted on the Chinese renminbi as well as the U.S. dollar. As such, the renminbi might start to play the role of one of the few world reserve currencies in the international financial system, so long as the capital controls are removed and the financial system consolidates. Similarly, the rupee could increase in importance as a partial anchor for other currencies in South Asia.

Finally, we note that part of the cross-border capital flows observed for China and India reflect round-tripping activities by which domestic entities seek to take advantage of the tax and other advantages offered to foreign investors, in a context of high capital controls. To the extent that such differential treatment is eliminated in the future through further financial liberalization, the gross scale of the international balance sheets as currently measured would shrink.

\section{IV.c. What Is the Contribution of China and India to Global Imbalances?}

China's and India's current net foreign asset positions are small in global terms. Table 1 shows that China was the world's 10th largest creditor in 2004, and India was the 16th largest debtor. Moreover, both imbalances are relatively small in absolute terms.

\footnotetext{
${ }^{31}$ As discussed in Eichengreen and Park (2003) and Eichengreen and Luengnaruemitchai (2004), there is also room for regional cooperative policies (for instance, in developing a more integrated Asian bond market).
} 
Although India has returned to running a current account deficit, the Chinese current account surplus has continued to increase.

Based on a combination of a calibrated theoretical model and non-structural crosscountry regressions, Dollar and Kraay (2006) argue that liberalization of the external account and continued progress in economic and institutional reform should result in average current account deficits in China of 2 percent to 5 percent of GDP over the next 20 years, with the net foreign liability position possibly reaching 40 percent of GDP by 2025 . $^{32}$ Indeed, any general neoclassical approach would predict that China should be a net liability nation because productivity growth and institutional progress in a capitalpoor country offering high rates of return should boost investment and reduce savings at the same time. Although there has been no similar study for India, similar reasoning applies - with greater capital account openness and continued reform, India might run persistently higher current account deficits during its convergence process.

It is worth recalling that the development experience of some other Asian nations has involved sustained phases of considerable current account deficits. For instance, the current account deficits of the Republic of Korea and Singapore averaged 5.0 percent and 14.4 percent respectively during 1970-82, with the net foreign liabilities of the former peaking at 44.2 percent of GDP in 1982 and those of the latter peaking at 54.2 percent of GDP in 1976 (although in those cases the economies were significantly smaller in relative terms than what China and India are today). Likewise, in Europe, the neoclassical model is performing well with a strong negative correlation between income per capita and the current account balance, driven by large current account deficits in the poorer members of the European Union and the emerging economies of Central and Eastern Europe. More formally, Dollar and Kraay (2006) consider the determinants of net foreign asset positions in a cross-country regression framework that controls for productivity, institutional quality, and country size and they find that the China dummy is significantly positive - the Chinese net foreign asset position is too high relative to the predictions of the empirical model. Similarly, along the time series dimension, Lane and Milesi-Ferretti (2002) find that increases in per capita output are associated with a decline in the net foreign asset position for developing countries, contrary to the recent Chinese experience.

If the neoclassical predictions about the impact of institutional reform and capital account liberalization in China take hold, the global effect of a sustained current account deficit on the order of 5 percent of GDP per annum soon would become significant. If India also ran a 5 percent deficit and projections about the superior growth rate of these countries turn out to be true, Lane (2006) calculates that the combined deficits of China and India would reach 1.23 percent of G7 GDP by 2015 and 2.16 percent of G7 GDP by 2025 (by comparison, the U.S. deficit in 2005 was 2.41 percent of G7 GDP). Clearly, the global impact of current account deficits of this absolute magnitude would represent a major call on global net capital flows. Of course, the feasibility of deficits of this magnitude requires that there are countries in the rest of the world willing to take large net creditor positions.

\footnotetext{
${ }^{32}$ The natural evolution is that the scale of current account deficits will taper off and, if these countries become rich relative to the rest of the world, this phase may be followed by a period in which they become net lenders to the next wave of emerging economies. See also Summers (2006).
} 
If that is not the case, the desired savings and investment trends will translate into higher world interest rates rather than large external imbalances.

Although a neoclassical approach predicts that these countries could run much larger current account deficits, there is substantial disagreement about these predictions. Critics would argue that the neoclassical predictions do not take into account several factors unique to China and India and do not explain the recent past and distinctive nature. More specifically, several studies have suggested that savings rates are likely to remain high in China and India. For instance, Fehr, Jokish, and Kotlikoff (2005) interpret China's recent savings behavior as indicative of a low rate of time preference, they and suggest that China will remain a large net saver. Based on household survey data, Chamon and Prasad (2005) make demographic projections and predict higher household saving rates over the next couple of decades. Finally, Kuijs (2006) argues that structural factors mean that savings and investment rates in China will decline only mildly in the decades ahead. With respect to India, Mishra (2006) argues that the upward trend of Indian saving rates will continue. For instance, India's working-age population as a percentage of total population is expected to peak in 2035, much later than in other Asian economies.

Although demographic considerations may mean that savings rates are unlikely to plummet, it is plausible that further domestic financial development and capital account liberalization will induce a downward adjustment in the savings rate. For instance, Chamon and Prasad (2005) point out that the savings rate (especially for younger households) could decline if the growing demand for consumer durables were to be financed through the development of consumer credit. This would be reinforced by the liberalization of controls on capital flows that would provide greater competition in the domestic financial sector and improved opportunities for risk diversification, leading to more lending and less savings. In addition, there are recent indications that China plans a range of policy initiatives to raise the domestic level of consumption. ${ }^{33}$ Furthermore, over time, improvements in social insurance systems and provision of public services in both countries would reduce over time the self-insurance motivation of high savings rates.

To project the net position, it is important also to consider the prospects for the level of investment. In China and India, a combination of an improvement in domestic financial intermediation and capital account liberalization would raise the attractiveness of these countries as a destination for external capital and would enhance the ability of domestic private firms to pursue expansion plans. ${ }^{34}$ In the Indian case, a primary driver of larger current account deficits could be a higher rate of public investment, in view of the deficiencies in the current state of its public infrastructure.

\footnotetext{
${ }^{33}$ See the media coverage of the March 2006 Party Congress.

${ }^{34}$ In view of the high level of inefficient investment in China, it is plausible that corporate governance reforms and higher dividend payouts (together with domestic financial deepening and external liberalization) could lead to a reduction in the absolute level of investment in tandem with a decline in the level of enterprise savings. With an increase in market-driven investment and a decline in savings, the prediction of an increased current account deficit still would hold.
} 
In terms of net positions, Dooley, Folkerts-Landau, and Garber (2003) argued that it is possible to rationalize persistent current account surpluses by appealing to the reduction in country risk that may be associated with the maintenance of a net creditor position. However, even if such an externality effect is present, it may not survive a liberalization of controls on capital flows, in view of the powerful private incentives to invest more and save less.

In summary, our projection is that, all else being equal, a combination of further domestic financial development and capital account liberalization will unleash forces that induce larger net resources flows into China and India. Although this projection seems quite robust as a qualitative level, we recognize that different forces may operate in the other direction. In particular, a stalling of the reform process in either country would reduce the impetus for greater net inflows. Moreover, even if market-orientated reform continues, the relative pace of demographic change in China and, at a later date, in India will be an important force toward a more positive net external position. Even in that case, the composition of capital flows will be radically different than the current pattern, with the net balance the product of much larger gross inflows and gross outflows.

\section{IV.d. Do China and India Pose Additional Global Risks?}

In the preceding discussion, we have speculated as to the global impact of the further integration of China and India into the international financial system and a rebalancing of their international balance sheets, especially in regard to a decline in the relative importance of official reserves. While we have focused on the likely medium-term effects of these shifts, it is also important to acknowledge that integrating China and India into the international financial system is not risk free.

Indeed, Prasad, Rogoff, Wei, and Kose (2003) document that financial globalization is typically associated with an initial increase in consumption volatility for developing countries and there have been many currency and banking crises in recent decades that may have been compounded in part by external financial liberalization. Of course, these findings do not in themselves represent a blanket argument against international financial integration. In fact, they point out that financial globalization reduces volatility for those countries that exceed a threshold level of domestic financial development, indicating that the source of instability is the interaction of international capital flows with an illprepared domestic financial system. Ranciere, Tornell, and Westermann (2005) show that long-term output growth increases after external liberalization so that the output reversals associated with "bumpiness" are more than offset by a faster underlying growth rate. On the financial front, Kaminsky and Schmukler (2003) show that although financial markets might become more volatile in the immediate aftermath of liberalization, volatility is diminished in the longer term.

For China, the 1997-98 Asian financial crisis appears to have shaped its approach to external liberalization such that it minimizes the risks involved. In the Indian case, its own external debt crisis in the early 1990s has strongly influenced its subsequent strategy. Both countries have sought to limit the accumulation of foreign currency 
external debt to private creditors, which has been the central vulnerability in most of the financial crises over the last decade. Similarly, the accumulation of large official reserve holdings provides a good measure of self-insurance in the event of a sudden stop in capital inflows.

In the preceding sections, we have documented that China and India represent only a relatively small share of global external liabilities. For this reason, the spillover impact of a reversal in China or India could be somewhat limited in magnitude because the exposure of international investors to these countries remains quite low. This does not mean, however, that these countries pose no risks to the global economy.

First, the banking sectors in both countries are a source of vulnerability. This is of particular concern in China, where a history of directed lending to state-owned enterprises, a significant volume of non-performing loans, and low levels of efficiency mean that the transition to a commercially based system is far from complete. Solvency concerns could lead to banking instability if restrictions on capital outflows were lifted and weaknesses in the banking sector are not addressed before financial liberalization, with depositors opting to deal with better-capitalized international banks. ${ }^{35}$ Moreover, credit has expanded in recent years, with the risk that the quality of new loans is too low (Setser 2005). In the Indian case, as emphasized by Kletzer (2005), the assets of the banking sector have been heavily concentrated in domestic government debt - typically carrying a low interest rate and having a relatively long maturity, with attendant exposure to an increase in interest rates. Significant progress has been made in the last couple of years, however, with a decline in the holdings of government securities, an improvement in risk management, lower levels of non-performing loans and credit risk, and improved profitability.

A second potential vulnerability relates to the effect of greater exchange rate flexibility on the balance sheets of domestic entities. One manifestation is the much-discussed capital losses on China's and India's large dollar reserve holdings in the event of significant currency appreciation against the dollar. ${ }^{36}$ Aside from the value of the local currency with respect to the U.S. dollar, fluctuations in international asset prices and exchange rates will be an increasingly strong influence on the balance sheets of banks, firms, and households in China and India. The importance of these valuation effects increases with financial globalization, affecting the dynamics of the external positions (Lane and Milesi-Ferretti 2006). The challenge is to ensure that the domestic financial sector has the capacity to manage such balance sheet risks.

Finally, a third concern is the political economy of FDI. Political opposition from local entities may reduce the inward flow of new FDI. Export-orientated FDI may be harmed

\footnotetext{
${ }^{35}$ For this reason, Obstfeld (2005) recommends a gradual approach to capital account liberalization and suggests that China could learn from other countries (Chile, Israel) that have strengthened domestic financial systems before fully opening the capital account.

${ }^{36}$ Setser (2005) also stresses that, contrary to the norm in other developing countries, many Chinese firms are financially exposed should such currency appreciation occur, because they sell in foreign currency and have debts in domestic currency.
} 
by the rise of protectionist pressures in destination markets. Because China is so highly integrated into an Asian manufacturing chain, this could have adverse upstream spillover effects on other Asian countries, and create a disruption in FDI.

\section{Conclusions}

In this paper, we have studied the impact of China and India on the international financial system by examining and comparing both countries, analyzing different aspects of their international financial integration, and linking the patterns in their international balance sheets to policies regarding their domestic financial systems. Given the evolution and probable changes in their domestic financial sectors, this analysis is relevant in projecting the future evolution of the international financial system.

The main current international financial impact of India and particularly China has been in their accumulation of unusually high levels of foreign reserves. Another salient aspect of their integration is the asymmetry in the composition of their gross assets and liabilities. Their assets are low-return foreign reserves, which are liquid and protect them against adverse shocks, but they carry a high opportunity cost. Their liabilities are FDI, debt, and portfolio equity, which usually yield a higher rate of return. FDI has been relatively more important in China, with portfolio investment taking a lead role in India. Despite recent attention and concerns regarding their effects on developing countries, China and India do not seem to have been crowding out investment elsewhere and, despite a recent acceleration in activity, are not yet major accumulators of non-reserve foreign assets. A striking aspect of their integration has been the reduction in their net liability positions, defying neoclassical predictions that they should be running large current account deficits given their level of development. Whether the shift in their net positions is transient or permanent is a central issue in assessing the future impact of China and India on the international financial system.

We have argued that the effect of China and India on the international financial system is fundamentally linked to the evolution of their domestic financial systems, including their exchange rate and capital account liberalization policies. As both China and India are likely to undergo further financial development and liberalization, these countries are set to have an ever-increasing effect on the international financial system. We project that the nature of their integration with the international financial system is likely to be reshaped. At one level, the composition of the international balance sheets will become less asymmetric - with a greater accumulation of non-reserve foreign assets and a more balanced distribution of foreign liabilities among FDI, portfolio equity, and debt. This rebalancing should be good news for developing countries that may receive a greater share of the outward investment flows from China and India. At another level, there is a strong (but not undisputed) prospect that these countries might experience a sustained period of substantial current account deficits. In view of their increasing share in global output, the prospective current account deficits of China and India may be a central element in the next phase of the "global imbalances" debate. If this scenario plays out, other potential borrowers will receive smaller net capital flows, will face a higher cost of capital, or will encounter both problems. 
As always, the future developments are difficult to predict and are conditional on other factors (like distinct demographic trajectories and economic reforms), domestic policy options, and the international environment. Key aspects to monitor when analyzing the possible paths that China and India may follow (and their impact on the international system) include the following elements. First, it is essential to watch what approaches these countries adopt regarding their exchange rate policies, particularly in light of the sustained appreciation pressure (from the market and the international political environment). Although significant appreciation may be resisted in the short run by further reserve accumulation, this is increasingly costly and may compromise other policy objectives. Second, a sharp correction in the U.S. dollar relative to other major currencies may act as an external trigger for a switch to greater exchange rate flexibility in China and India because the renminbi and the rupee would become (more) undervalued relative to those major, relevant currencies. Indeed, concerns about such a correction also may prompt these countries to alter the currency composition of reserves, affecting interest rates and possibly exchange rates (at least in the short run). A third key component to monitor is how fast these countries substitute reserve holdings for other assets abroad. To the extent that the international environment remains favorable, it is likely that some of the ideas described above to shift away from traditional reserve holdings start to materialize. Fourth, a fully-fledged liberalization of capital controls remains unlikely in the short to medium term, in view of the outstanding weaknesses in coping with unrestricted debt flows. It is likely, however, that these countries will continue to liberalize their financial sectors, with implications for the composition of their international balance sheets and net foreign asset positions. The exact form of this liberalization process, its timing, and its pace are still to be determined and will remain a subject of attention. For all these reasons, we anticipate that the international financial integration of China and India is set to undergo significant reshaping in the coming years. 


\section{References}

Aizenman, Joshua and Jaewoo Lee, 2005, "International Reserves: Precautionary versus Mercantilist Views, Theory and Evidence.” NBER Working Paper No.11366.

Allen, Franklin, Jun Qian, and Meijun Qian, 2005, “China’s Financial System: Past, Present, and Future." Mimeo, Wharton School.

Allen, Franklin, Rajesh Chakrabarti, Sankar De, Jun Qian, and Meijun Qian, 2006, "Financing Firms in India." Mimeo, Wharton School.

Bai, Chong-En, 2006, "The Domestic Financial System and Capital Flows: China." Mimeo, Tsinghua University.

Beck, Thorsten, Asli Demirgüç-Kunt, and Ross Levine, 2006, "A New Database on Financial Development and Structure (1960-2004)." World Bank Policy Resarch Working Paper No. 2146.

Blanchard, Olivier and Francesco Giavazzi, 2005, "Rebalancing Growth in China: A Three Handed Approach." MIT Working Paper 05-32.

Boyreau-Debray, Genevieve and Shang-Jin Wei, 2005, "Pitfalls of a State Dominated Financial System: The Case of China." NBER Working Paper No. 11214.

Caballero, Ricardo, Emmanuel Farhi, and Pierre-Olivier Gourinchas, 2006, "An Equilibrium Model of Global Imbalances and Low Interest Rates.” NBER Working Paper No. 11996.

Cerra, Valerie and Sweta Chaman Saxena, 2002, "What Caused the 1991 Currency Crisis in India?" IMF Staff Papers, 49(3), 395-425.

Chamon, Marcos and Eswar Prasad, 2005, "Determinants of Household Saving in China." Mimeo, International Monetary Fund.

Chari, Anusha and Nandini Gupta, 2006, "The Influence of Domestic Firms on Foreign Direct Investment Liberalization." Mimeo, University of Michigan.

Corbett, Jenny and Tim Jenkinson, 1996, "The Financing of Industry, 1970-1989: An International Comparison." Journal of the Japanese and International Economies, 10, 71-96.

Dollar, David and Aart Kraay, 2006, "Neither a Borrower Nor a Lender: Does China's Zero Net Foreign Asset Position Make Economic Sense?" Forthcoming in Journal of Monetary Economics.

Dooley, Michael, David Folkerts-Landau, and Peter Garber, 2003, "An Essay on the Revived Bretton Woods System.” NBER Working Paper No. 9971.

Dossani Rafiq and Martin Kenney, 2002, "Creating an Environment for Venture Capital in India." World Development, 30(2), 227-253.

Eichengreen, Barry, 2004, "Global Imbalances and the Lessons of Bretton Woods." NBER Working Paper No.10497.

Eichengreen, Barry and Pipat Luengnaruemitchai, 2004, "Why Doesn't Asia Have Bigger Bond Markets?" Korea University/BIS Conference "Asian Bond Market Research," Seoul, March.

Eichengreen, Barry and Yung Chul Park, 2003, "Why Has There Been Less Financial Integration in Asia than in Europe?" Institute of European Studies. Political Economy of International Finance. Working Paper PEIF-4.

Eichengreen, Barry and Hui Tong, 2005, "Is China's FDI Coming at the Expense of Other Countries?" NBER Working Paper No. 11335. 
European Central Bank, 2006, "The Accumulation of Foreign Reserves." Occasional Paper Series No. 43.

Fehr, Hans, Sabine Jokisch, and Laurence Kotlikoff, 2006, "Will China Eat Our Lunch or Take Us Out to Dinner? Simulating the Demographic, Fiscal, and Economic Transition Paths of the US, EU, Japan, and China." Forthcoming in Ito, Takatoshi and Andrew Rose (eds.), Fiscal Policy and Management in East Asia. University of Chicago Press.

Fernandes, Kshama and Ajay Shah, 2001, "The Relevance of Index Funds for Pension Investment in Equities." In Holzmann, Robert and Joseph Stiglitz (eds.), New Ideas About Old Age Security: Toward Sustainable Pension Systems in the 21st Century. World Bank.

Frankel, Jeffrey, 2006, "On the Yuan: The Choice between Adjustment Under a Fixed Exchange Rate and Adjustment under a Flexible Rate." CESifo Economic Studies 52(2), 246-275.

Gao, Sheldon, 2002, “China Stock Market in a Global Perspective.” Dow Jones Indexes Report.

Genberg, Hans, Robert McCauley, Yung Chul Park, and Avinash Persaud, 2005, Official Reserves and Currency Management in Asia: Myth, Reality and the Future. Center for Economic Policy Research.

Goldstein, Morris and Nicholas Lardy, 2005, "China's Role in the Revived Bretton Woods System: A Case of Mistaken Identity." Institute for International Economics Working Paper No. 05-2.

Goodfriend, Marvin and Eswar Prasad, 2006, “A Framework for Independent Monetary Policy in China." IMF Working Paper No. 06/111.

Government of India, 2005, "Investing in India: Foreign Direct Investment Policy \& Procedures." Department of Industrial Policy and Promotion, Ministry of Commerce and Industry.

Green, Stephen, 2004, "Enterprise Reform and Stock Market Development in Mainland China." Deutsche Bank Research, China Special.

Gunter, Frank, 2004, "Capital Flight from China: 1984-2001." China Economic Review, 15(1), 63-85.

Huang, Yasheng, 2006, "Assessing Financing Constraints for Domestic Private Firms in China and India: Evidence from the WBES Survey." Indian Journal of Economics and Business, Special Issue China and India, 69-92.

International Monetary Fund, 2006, Global Financial Stability Report.

International Monetary Fund, 2005, World Economic Outlook, September 2005.

International Monetary Fund, World Economic Outlook Database, September 2006. URL: http://www.imf.org/external/pubs/ft/weo/2006/02/data/index.htm.

Jaimovich, Dany and Ugo Panizza, 2006, "Public Debt around the World." IDB Research Department Working Paper No. 561.

Ju, Jiandong and Shang-Jin Wei, 2006, "A Solution to Two Paradoxes of International Capital Flows.” Mimeo, International Monetary Fund.

Kaminsky, Graciela and Sergio Schmukler, 2003, "Short-Run Pain, Long-Run Gain: The Effects of Financial Liberalization.” NBER Working Paper No. 9787. 
Kochhar, Kalpana, Utsav Kumar, Arvind Subramanian, Raghuram Rajan, and Ioannis Tokatlidis, 2005, "India's Pattern of Development: What Happens, What Follows." IMF Working Paper No. 06/22.

Kletzer, Kenneth, 2005, "Liberalizing Capital Flows in India: Financial Repression, Macroeconomic Policy and Gradual Reforms." In Bery, Suman, Barry Bosworth, and Arvind Panagariya (eds.) India Policy Forum 2004. Brookings Institution Press.

Kuijs, Louis, 2005, "Investment and Savings in China." World Bank Policy Research Working Paper No. 3633.

Kuijs, Louis, 2006, "China in the Future: A Large Net Saver or Net Borrower?" Mimeo, World Bank.

Lane, Philip, 2006, "The International Balance Sheets of China and India." Mimeo, Trinity College Dublin.

Lane, Philip and Gian Maria Milesi-Ferretti, 2002, "Long-Term Capital Movements." NBER Macroeconomics Annual 16, 73-116.

Lane, Philip and Gian Maria Milesi-Ferretti, 2006, "The External Wealth of Nations Mark II: Revised and Extended Estimates of Foreign Assets and Liabilities, 19702004." IMF Working Paper No. 06/69.

Laurenceson, James, 2002, "External Financial Liberalization and Foreign Debt in China." University of Queensland Discussion Paper Series.

Li, Chunxiang, Andong Zhu, and Gerald Epstein, 2005, "Capital Flight from China, 1982-2001." In Epstein, Gerald (ed.), Capital Controls and Capital Flight from Developing Countries. Edward Elgar.

Li, David, 2006, "Large Domestic Non-Intermediated Investments and Government Liabilities: Challenges Facing China's Financial Sector Reform.” Mimeo, Tsinghua University.

Lim, Edwin, Michael Spence, and Ricardo Hausmann 2005, "China and the Global Economy: Medium-Term Issues and Opinions." Center for International Development Working Paper No. 126.

Ma, Guonan and Robert McCauley, 2002, "Rising Foreign Currency Liquidity of Banks in China." BIS Quarterly Review, September, 67-74.

Ma, Guonan and Robert McCauley, 2006, "Are China's Capital Controls Still Binding?" Mimeo, Bank of International Settlements.

McKinnon, Ronald, 2005, "China's New Exchange Rate Policy: Will China Follow Japan into a Liquidity Trap?" The Weekly Economist.

Mei, Jianping, Jose Sheinkman, and Wei Xiong, 2005, "Speculative Trading and Stock Prices: Evidence from the Chinese A-B Share Premia." Mimeo, Princeton University.

Mercereau, Benoit, 2005, "FDI Flows to Asia: Did the Dragon Crowd out the Tigers?" IMF Working Paper WP/05/189.

Mishra, Deepak, 2006, "Financing India's Rapid Growth and its Implications for the Global Economy." Mimeo, World Bank.

Modigliani, Franco, and Shi Larry Cao, 2004, "The Chinese Saving Puzzle and the LifeCycle Hypothesis." Journal of Economic Literature, 42(1), 145-170.

Naughton, Barry, 2006, "Top-Down Control: SASAC and the Persistence of State Ownership in China." Mimeo, University of California, San Diego.

OECD, 2005, OECD Economic Surveys, Vol. 2005/13, Paris. 
Obstfeld, Maurice, 2005, "The Renminbi's Dollar Peg at the Crossroads." Mimeo, University of California, Berkeley.

Obstfeld, Maurice and Kenneth Rogoff, 2005, "Global Current Account Imbalances and Exchange Rate Adjustments.” Brookings Papers on Economic Activity, 2005(1), 67146.

Patnaik, Ila and Ajay Shah, 2006a, "The Interplay Between Capital Flows and the Domestic Indian Financial System." Mimeo.

Patnaik, Ila and Ajay Shah, 2006b, "India's Experience with Capital Flows: The Elusive Quest for a Sustainable Current Account Deficit." Forthcoming in Edwards, Sebastian (ed.), Capital Controls and Capital Flows in Emerging Economies: Policies, Practices and Consequences. University of Chicago Press.

Prasad, Eswar (ed.), 2004, "China's Growth and Integration into the World Economy," IMF Occasional Paper No. 232.

Prasad, Eswar, Kenneth Rogoff, Shang-Jin Wei, and Ayhan Kose, 2003, "Effects of Financial Globalization on Developing Countries: Some Empirical Evidence." IMF Occasional Paper No. 220.

Prasad, Eswar and Raghuram Rajan, 2005, "Controlled Capital Account Liberalization: A Proposal.” IMF Policy Discussion Paper No. 05/7.

Prasad, Eswar and Raghuram Rajan, 2006, "A Framework for Independent Monetary Policy in China." IMF Working Paper No. 06/111.

Prasad, Eswar and Shang-Jin Wei, 2005, "China's Approach to Capital Inflows: Patterns and Possible Explanations." IMF Working Paper No. 05/79.

Ranciere, Romain, Aaron Tornell, and Frank Westermann, 2005, "Systemic Crises and Growth.” NBER Working Paper No.11076.

Rodrik, Dani, 2005, "Growth Strategies." In Aghion, Philippe and Durlauf, Steven (eds.), Handbook of Economic Growth. North-Holland.

Rodrik, Dani, 2006a, "Goodbye Washington Consensus, Hello Washington Confusion?" Mimeo, Harvard University, Kennedy School of Government.

Rodrik, Dani, 2006b, "The Social Cost of Foreign Exchange Reserves." Forthcoming in International Economic Journal.

Setser, Brad, 2005, "The Chinese Conundrum: External Financial Strength, Domestic Financial Weakness." CESifo Conference "Understanding the Chinese Economy." Munich, June.

Shah, Ajay, 1995, “The Indian IPO Market: Empirical Facts.” Technical Report, Centre for Monitoring Indian Economy.

Shah Ajay and Susan Thomas, 1998, "Market Microstructure Considerations in Index Construction." In CBOT Research Symposium Proceedings, 173-193. Chicago Board of Trade.

Sharma, Kishor, 2000, "Export Growth in India: Has FDI Played a Role?" Yale University Economic Growth Center Discussion Paper No. 816.

Shen, Jian-Guang, 2001, "China's Exchange Rate System after WTO Ascension: Some Considerations." Bank of Finland Institute for Economies in Transition.

Summers, Lawrence, 2006, "Reflections on Global Account Imbalances and Emerging Markets Reserve Accumulation.” L.K. Jha Memorial Lecture, Reserve Bank of India, Mumbai, March. 
Thomas, Susan, 2005, "How the Financial Sector in India Was Reformed." In Narayanan, S. (ed.) Documenting Reforms: Case Studies from India. Observer Research Foundation.

UNCTAD, 2005, Trade and Development Report.

Wang, Tao, 2004, "Exchange Rate Dynamics." In Prasad, Eswar (ed.), "China's Growth and Integration into the World Economy: Prospects and Challenges." IMF Occasional Paper No. 232.

Warnock, Francis and Veronica Warnock, 2006, "International Capital Flows and U.S. Interest Rates." Mimeo, Darden School of Business, University of Virginia.

Winters, L. Alan and Shahid Yusuf, 2007, "Introduction: Dancing with Giants." in L. Alan Winters and Shahid Yusuf (eds.) Dancing with Giants: China, India, and the Global Economy, World Bank and Institute of Policy Studies.

World Bank, 2002, "Box 2.3: Round-tripping of capital flows between China and Hong Kong (China)." Global Development Finance 2002: Financing the Poorest Countries, 41.

World Bank, 2005, Economic Reform in the 1990s: Learning from a Decade of Reform. World Bank.

Xiao, Geng, 2004, "People's Republic of China's Round-Tripping FDI: Scale, Causes and Implications." ADB Institute Discussion Paper No. 7.

Zhao, Min, 2006, "External Liberalization and the Evolution of China's Exchange System: An Empirical Approach.” Mimeo, World Bank. 


\section{Appendix I: Evolution of China's Domestic Financial Sector}

This appendix provides additional details on the developments in the domestic financial sector in China, and the links to its international financial integration.

\section{AI.a.i. Capital Account Liberalization and Exchange Rate Policies}

China's financial liberalization policies started in 1978 as part of a broader political decision to transform China into a modern, more market-oriented economy. The liberalization started from a very low base: only a few state-owned corporations participated in foreign trade and all the foreign exchange transactions were managed by the state. In terms of the form of liberalization, China has adopted a gradualist approach to financial liberalization, including the opening of the capital account. ${ }^{37}$ In the first stage of liberalization, during the 1980s and 1990s, the main focus was on promoting inward direct investment flows, on account of its contribution to technology transfer and export promotion and its putative stability.

An increasing number of regions were opened to FDI during this early phase of liberalization, and by the end of the 1990s most of the mainland was open. Two types of incentives were given to foreigners wanting to invest directly in China: (i) the government committed itself to a policy of not nationalizing joint ventures and foreign firms; and (ii) the regions that were opened were also allowed to give tax incentives to FDI. These policies led to a surge of FDI to China during the 1990s. In 2002, a four-tier classification was introduced, in which foreign investment was encouraged, permitted, restricted, or banned, depending on the sector. This in practice meant a further opening to FDI.

Investment by foreigners in China's stock markets has been permitted since 1992. This primarily takes the form of investment in class $\mathrm{H}$ shares (i.e. listed in Hong Kong (China)), with class B shares (foreign-currency shares issued in China) much less popular. ${ }^{38}$ The RMB-denominated class A shares were reserved for domestic residents until 2002, but qualified foreign institutional investors (QFIIs) have been permitted to purchase class A shares since then, subject to restrictions that are detailed in Prasad and Wei (2005). Even after these measures to liberalize the Chinese stock market were implemented, there are still a number of features that limit the attractiveness of Chinese equity to foreign investors. The most important problem is the large overhang of shares that have been retained by the state in formerly state-owned enterprises, which also reduces the level of investor protection for small outside shareholders. ${ }^{39}$

As to debt inflows, a much more cautious approach was adopted, since these were considered potentially volatile. Foreign borrowing is divided into planned and nonplanned borrowing. Planned borrowing includes borrowing by the government sector,

\footnotetext{
${ }^{37} \mathrm{~A}$ gradualist approach to capital account liberalization is increasingly supported in academic and policy circles - see, for example, World Bank (2005) and Rodrik (2006a).

${ }^{38}$ Since 2001, domestic residents have been entitled to invest in class B shares.

${ }^{39}$ See Gao (2002), Green (2004), Mei, Scheinkman, and Xiong (2005), and Naughton (2006).
} 
Chinese financial institutions, authorized Chinese enterprises, and short-term trade credits. Non-planned borrowing is limited to borrowing by foreign-funded enterprises and branches of foreign banks or joint venture banks. All planned borrowing is coordinated by the State Planning Commission and medium- and long-term commercial planned borrowing must be authorized by the State Administration of Foreign Exchange (SAFE). The People's Bank of China and the SAFE supervise and have to approve all bond issues abroad. Most of the domestic institutions that have been able to issue bonds abroad have been connected to the central government (Laurenceson 2002).

As a consequence of these measures, foreign investors wanting to invest in the Chinese market have had a limited range of instruments at their disposal, with direct investment being the instrument favored by the Chinese government's policies. Table 4 provides a summary of the liberalization measures in China in recent years, while Zhao (2006) provides a comprehensive narrative of the main phases in capital account policies since 1978.

With respect to private capital outflows, these have been heavily restricted until recently. A basic motivation has been to enable the state to control the domestic banking sector for instance, the ability of the government to impose an interest rate ceiling would be heavily compromised if domestic residents had greater freedom to place assets overseas. Restrictions on portfolio investment outflows also reflect a reluctance to allow too much discretion to an underdeveloped domestic institutional investor sector. The low level of FDI in Chinese foreign asset holdings similarly reflects the restrictions placed on the freedom of firms to make foreign acquisitions or establish overseas affiliates.

Despite these restrictions, there have been a number of recent policy moves to promote greater outward portfolio investment. For example, a 2002 pilot scheme to promote outward FDI was extended nationally in 2005, indicating that the currently low levels of foreign FDI assets may not persist into the future. Moreover, as documented by Zhao (2006), domestic insurance companies have been permitted to use their own foreign currency holdings to invest in international capital markets since 2004. Furthermore, on April 13, 2006, the government launched a qualified domestic institutional investor (QDII) program aimed at increasing the ability of domestic residents to invest in foreign securities, including stocks and bonds. The program stipulates that: (i) qualified banks may assemble funds in domestic currency from domestic institutions and individuals and invest them in fixed income products in international markets, (ii) qualified security firms may assemble funds from institutions and individuals and invest in international capital markets, including stock markets, and (iii) insurance companies may invest in foreign fixed income and monetary instruments.

A central consideration in China's financial liberalization policy is its relation to the exchange rate regime. Between 1981 and 1994, two exchange rates co-existed in practice, entailing an official rate and another one applied to exports and imports. During this period, enterprises were allowed to retain a portion of the foreign exchange they earned. Households were also limited in their purchase of foreign exchange (Shen 2001). In 1994, the dual exchange rate regime was ended and enterprises had to sell all their 
foreign exchange earnings to designated banks, with currency purchases permitted for commercial contracts. In April 1994, an inter-bank foreign exchange market was created, to replace the swap markets of the previous dual exchange rate regime. The swap markets were abolished in 1998, and since then all foreign exchange transactions have taken place in the inter-bank market. In December 1996, China introduced convertibility of the renminbi for current account transactions (in accordance with IMF charter's Article VIII provisions). After the end of the dual exchange rate, the de jure exchange rate regime has been a managed float, but the de facto exchange rate has been fixed to the U.S. dollar since 1995, albeit with a shift towards some level of flexibility since July 2005 (Wang 2004 and Zhao 2006). Maintaining a stable value of the exchange rate has been a policy priority in order to act as a domestic nominal anchor and to promote trade and FDI.

The liberalization measures have not reached the capital account, with the Chinese government not permitting convertibility for capital account transactions. The main features of the capital account controls are the following (Shen 2001). Capital brought in from abroad must be deposited in accounts in designated banks. Remittances and repayments from these accounts are subject to the approval of the State Administration of Foreign Exchange (SAFE). Inbound foreign capital must obtain SAFE approval to convert to RMB. As mentioned above, foreign borrowing must be approved by the SAFE, except for commercial borrowing with a maturity of less than three months. Outbound foreign investments by Chinese firms must also get SAFE approval. Since January 2003, permission from the SAFE is no longer required for domestic residents to borrow foreign exchange from domestic Chinese financial institutions (Prasad and Wei 2005).

There is a close association between the exchange rate regime and the capital account regime - the desire to maintain exchange rate stability is a major factor in the retention of capital controls, as described by the "impossible trinity" in international finance. Conversely, as argued by Prasad (2004), a combination of an open capital account and a rigid exchange rate peg could constitute the riskiest-possible policy regime for China, in view of the putative instability of such a regime for large, emerging market economies. In this way, capital account and exchange rate policies are intimately linked.

The retention of capital controls has enabled the government to have some degree of monetary policy autonomy, even with a quasi-fixed exchange rate. However, this is increasingly ineffective as the development and liberalization of the domestic financial system and the rapid growth in international trade facilitates greater evasion of these controls. ${ }^{40}$ As mentioned above when describing Table 3a, capital account restrictions have led to significant round-tripping: much of the recorded FDI inflows are suspected to be Chinese investment disguised as foreign to take advantage of the tax benefits to foreign investment. Hong Kong (China), the source of between 30 and 60 percent of FDI in the last ten years, has played an important role in this round-tripping of investment. Estimates of the extent of round-tripping range from 25 percent (World Bank 2002) to as

\footnotetext{
${ }^{40}$ While capital controls may be increasingly porous, Ma and McCauley (2006) show that controls remain binding in that there are differentials between offshore and onshore RMB interest rates.
} 
much as 50 percent (Xiao 2004). ${ }^{41}$ As mentioned in the text, the targeting of the exchange rate has had a powerful influence on the composition of China's international balance sheet.

The continued maintenance of an exchange rate peg may be defended on several grounds. McKinnon (2005) argues that it provides a nominal anchor for a country with weak domestic institutions. However, the most powerful case in its favor is made by proponents of the Bretton Woods II system that argue that the maintenance of a weak exchange rate (backed up by capital controls) retains its value in supporting an export-led development strategy (Dooley, Folkerts-Landau, and Garber 2003, Rodrik 2005). Another argument is that a move to a flexible exchange rate would increase fluctuations in the real exchange rate not linked to fundamentals. On the other hand, it is clear that greater exchange rate flexibility would provide greater autonomy in monetary policy, especially for a large country that could effectively develop a domestic nominal anchor. ${ }^{42}$ In turn, a more flexible exchange rate would weaken the incentive for speculative capital flows and reduce the pace of reserve accumulation. By providing greater monetary policy autonomy, it would also enable the relaxation of capital account restrictions. However, exchange rate flexibility is not a sufficient condition for a fully open capital account, in view of the vulnerabilities in the banking sector, to which we now turn.

\section{AI.a.ii. The Domestic Financial System}

China had a poorly developed domestic financial system until 1978. China's financial system consisted of a single bank: the People's Bank of China, which was controlled by the ministry of finance. This started to change as part of the process of economic reform. In 1979, the People's Bank of China became independent of the finance ministry, and in the period between 1978 and 1984 the "big four" state commercial banks were created. The Bank of China was to handle foreign exchange and investment, the People's Construction Bank of China (originally created in 1954) was set to handle fixed investment, the Agricultural Bank of China was to manage all the banking in the rural sector, and the Industrial and Commercial Bank of China was established to deal with all the other commercial business. Most bank deposits in 1979 belonged to enterprises and government agencies and organizations. In contrast, most deposits in 2002 were urban savings (Allen, Qian, and Qian 2005).

During the 1980s, some foreign banks were allowed to set branches in "Special Economic Zones." Starting in 1992, with Deng Xiaoping's "Southern Tour," the banking system was further deregulated and more state and local government banks were created. In 1995, Morgan Stanley and the People's Construction Bank of China started the first joint-venture investment bank. Inter-bank lending and bond markets were established in 1994 and 1997. The early 1990s also saw the creation of China's stock exchanges: Shanghai in 1990 and Shenzhen in 1991.

\footnotetext{
${ }^{41}$ Also see Gunter (2004) and Li, Zhu, and Epstein (2005) for estimations of capital flight.

${ }^{42}$ See Blanchard and Giavazzi (2005), Prasad, Rogoff, Wei, and Kose (2003), Frankel (2006), and Goodfriend and Prasad (2006).
} 
The financial sector developed as the system was gradually liberalized. This deepening has occurred to different extents and with varying idiosyncrasies in the banking sector, the stock market, and the bond market, what makes it essential to understand what lies behind the raw figures.

Regarding the banking sector, Figure 8 shows that the banking sector has expanded considerably since 1991. But despite this growth, the banking sector is still dominated by the "big four" state-owned banks, geared to lend to the state-owned firms, while the economy has increasingly shifted towards private firms. ${ }^{43,44}$ State-owned banks are under increasing pressure to reduce the quantity of non-performing loans. In fact, nonperforming loans (NPL) represent a significant part of the assets of Chinese banks. According to the People's Bank of China (PBC), the NPL ratio of the big four banks stood at 16 percent in 2004, albeit down from 20 percent at the end of 2003. In the past, official statements suggested that 20-25 percent of all loans were non-performing, with six to seven percent unrecoverable.

The Chinese stock market expanded considerably in the last 15 years. The market was almost non-existent in 1991 but 1,384 companies were listed and market capitalization reached almost 40 percent of GDP by 2004 (Figure 9). However, the Chinese stock market still has several problems. As mentioned above, there is a large overhang of government-owned shares. Moreover, the government frequently bailouts the brokerage companies - mostly government owned. The brokerage companies have their own funds and also the accounts of their clients, and use both to invest. Officially, there should be a firewall between these two sources of funds, but in practice the brokerage companies take risks using their clients' funds. If losses are large, the government typically provides a bailout to cover its supervision failure. These bailouts are costly not only because of the resources required but also because they increase moral hazard by generating expectations of more bailouts (Bai 2006).

More generally, corporate governance in China remains far from best practice, especially in regard to state-owned enterprises. This is in stark contrast with India, where corporate governance ratings have been better than in most Asian countries (Patnaik and Shah 2006a). It is also in contrast with the focus of the Chinese government on guaranteeing safety for direct investment.

The bond market and, more generally, the total central government debt have also increased since 1991 (Figure 10). The bond market is dominated by the issuance of

\footnotetext{
${ }^{43}$ See Bai (2006), Goodfriend and Prasad (2006), and Li (2006) for recent analyses of the Chinese banking sector. Moreover, Boyreau-Debray and Wei (2005) argue that capital mobility among different regions in China is limited because the financial system is dominated by state-owned banks, and local governments are not willing to see capital flow out of their regions.

${ }^{44}$ Allen, Qian, and Qian (2005) classify Chinese firms in three sectors: the state sector (which is comprised of state owned enterprises, SOEs), the listed sector (which includes firms listed in the stock markets, mostly former SOEs), and the hybrid sector (which includes privately- or individually-owned firms, but also firms partially owned by local governments, because they behave similarly). They find that hybrid firms are the ones that rely the most on "self-fundraising," which includes financing from retained earnings, borrowing from local governments, communities, and other investors.
} 
government bonds, with the corporate bond market expanding in recent years but from a very low base.

Except in the case of turnover, all the indicators of capital market depth are lower than those in the G7 countries and in some cases lower than those in other emerging economies. But the high turnover ratio has been linked to high speculation in small capitalization stocks rather than as a sign of a liquid stock market. Mei, Sheinkman, and Xiong (2005) document that during the 1990s there has been large price differences between the A and B shares of the same firms, and relate this fact to the high turnover in the A-share market, relative to the B-share market. They find that the firms with a high "A-B premium" are also the firms with high turnover ratios, and also with high volatility of returns. They relate this high price-high turnover relation to the presence of shortselling constraints. Furthermore, Gao (2002) argues that the predominance of small-cap stocks and the high volatility make it difficult to diversify and introduce index products, which would be attractive to foreign investors wanting to participate in the Chinese market.

Given the underperformance of the financial system, especially the weak balance sheets of the banks, many have called for a deepening of the reform process. For instance, the OECD (2005) argues that financial reform in China will involve changing the structure of the banking system so that it can better support the real economy, developing capital markets and institutional investors, and strengthening the ability of financial institutions to behave commercially and manage risks prudently. ${ }^{45}$

Finally, an important factor underlying the underdevelopment of the domestic capital markets is the limited development of the domestic institutional investment sector (insurance companies, pension funds, and mutual funds), which would provide a natural investor base for domestic equities and bonds. ${ }^{46}$ The development of this sector could also offer a natural vehicle for the domestic private sector to exploit the gradual lifting of restrictions on outward portfolio investment to acquire foreign portfolio assets. The QDII program, described above, may help speed up the development of the domestic institutional investor sector and thus create a larger investor base for domestic assets.

\footnotetext{
${ }^{45}$ Goodfriend and Prasad (2006) recommend that a new agency be established to directly subsidize stateowned enterprises, thereby relieving the banking sector of the responsibility to support non-viable firms. In 2004-2005, China transferred 60 billion dollar in reserves to improve the capital base of several stateowned banks.

${ }^{46}$ A number of steps have been taken to develop the institutional investment sector. The insurance sector has been open to joint ventures since 2002 and restrictions on foreign insurance companies were greatly relaxed in 2005. Qualified foreign investment institutions (QFIIs) that meet regulatory approval have been allowed to invest in the domestic capital market since 2002. See Zhao (2006).
} 


\section{Appendix II: Evolution of India's Domestic Financial Sector}

This appendix provides additional details on the developments in the domestic financial sector in India, and the links to its international financial integration.

\section{AII.b.i. Capital Account Liberalization and Exchange Rate Policies}

The Indian economy, from independence in 1947 until the early 1990s, was characterized by a system of licensing and protection that inhibited the growth of the corporate sector and contributed to corruption and inefficiency. Many industries and strategic sectors were beyond the reach of the private sector, and 90 percent of the banks were nationalized after independence, starting in 1969. Many sectors were restricted to "small scale" firms, to promote employment. During this period, current account deficits were financed mostly with debt and official flows.

India experienced widening current account deficits during the 1980s, driven by a deteriorating fiscal position. The slow growth of India's trading partners, political problems inside India, and a rise in world oil prices in 1990 precipitated a severe financial crisis in the early 1990s (Cerra and Chaman Saxena 2002). Following that crisis, a series of reforms were instituted. As mentioned above, the goal was to spur Indian growth by fostering trade, FDI, and portfolio equity flows and also avoid debt flows, particularly short-term, that were perceived as being potentially destabilizing. Then an extensive but selective liberalization followed. Table 5 provides a summary chronology of the liberalization measures that have taken place in recent years. ${ }^{47}$ However, substantial controls remain.

The discouragement of external debt has restricted the ability of domestic entities to issue bonds on international markets and the entry of foreign investors to the domestic bond market. ${ }^{48}$ Hence, the market for private bonds remains underdeveloped, as shown in Figure 10. The restrictions on external debt are heavily influenced by memories of India's debt crisis in the early 1990s, with the composition of capital inflows subsequently shifting towards a much higher ratio of equity to debt flows.

As argued by Kletzer (2005), the state of the Indian public finances might be a major constraint on the relaxation of restrictions on capital outflows. ${ }^{49}$ Indian banks have been encouraged to hold government bonds, lowering the cost of financing public deficits, and have not been permitted to invest abroad. In fact, private credit over GDP has remained stagnant at low levels (Figure 8), while the level of government debt over GDP has

\footnotetext{
${ }^{47}$ Also see Government of India (2005) for a comprehensive description of the restrictions on inward investment and the papers listed as sources of the table.

${ }^{48}$ Patnaik and Shah (2006a) also highlight that the composition of external debt has shifted in recent years, with private debt and official government external debt in decline but the quasi-sovereign debt of parastatals increasing. A part of the quasi-sovereign debt is the State Bank of India debt, which is guaranteed by the government. The other part is non-resident Indian deposits in banks, which are not guaranteed, but the state has no track record of allowing non-trivial banks to fail.

${ }^{49}$ According to the Reserve Bank of India Statistical Handbook, Indian public debt was 82 percent of GDP by the 2004-2005 fiscal year, with the public deficit at eight percent of GDP.
} 
remained very high in India compared with other regions (Figure 10). External account liberalization could affect the Indian banking sector by increasing interest rates, which would hit banks that have long-maturity debt. However, as mentioned above, the strength of the banking system has improved significantly during the last couple of years.

Restrictions on FDI inflows have been progressively relaxed. Although FDI in many industries does not require government approval, some sectors are reserved, including agriculture, real estate below 25 acres, lotteries and gambling, atomic energy, broadcasting, and airlines. However, in part, the relatively low level of inward direct investment may also reflect greater political resistance to FDI in some regions and industries in India. ${ }^{50}$

Relative to the Chinese case, India has a much broader domestic institutional investor base that has allowed the domestic stock market to achieve a level of development that is far beyond what is normally the case for a country at its level of output per capita. ${ }^{51}$ In turn, this has facilitated the entry of foreign institutional investors (FIIs) that are permitted to take partial stakes in quoted Indian enterprises. ${ }^{52}$ FIIs can bring capital in and out of the country, use forward markets to hedge currency risks, and trade on the equity derivatives markets. By default, ownership of a firm by FIIs is limited at 24 percent, but the firm can raise this limit to 98 percent. There is also investment by foreign investors, who open "sub-accounts" with an FII. These sub-accounts may include collective investment funds and institutions, proprietary funds, and foreign corporations and individuals.

Restrictions on purchases by foreigners in the corporate and government bond markets are much stricter. In the government bond market, the limit to ownership by all FIIs together is 1.5 billion dollars. In the corporate bond market, the limit is 500 million dollars. There are also limits on the gross borrowing through banks or bond issuance abroad of all firms taken together.

As in China, the low level of foreign assets held by Indian private investors reflects the extent of restrictions on private capital outflows. However, as noted by Patnaik and Shah (2006a), the indications from the last couple of years are that the system is rapidly becoming liberalized, with a surge in outward direct investment by Indian firms. However, as in the Chinese case, the current constraints on asset allocation mean that official reserves are the predominant component of foreign assets, supported by a monetary regime that seeks to maintain a stable value of the rupee against the dollar.

Regarding the exchange rate regime, India's de jure system is freely floating since the early 1990s. But Patnaik and Shah (2006a) argue that the regime has actually been a de

\footnotetext{
${ }^{50}$ Chari and Gupta (2006) find that restrictions on FDI are greatest in those sectors where monopoly power is strongest and state-owned enterprises have a larger presence.

${ }^{51}$ Indeed, Patnaik and Shah (2006a) note that this successful development has even prompted foreign direct investors to raise funds through issuing shares on the domestic stock market.

${ }^{52}$ As outlined in Patnaik and Shah (2006a), no single FII can own more than ten percent of a quoted firm but it is possible that up to 100 percent of a firm may be owned by a multiplicity of FIIs.
} 
facto peg, consistent with "fear of floating," with some episodes of large currency movements to "let the steam off." The fixed periods have been 1993-95 and 1999-2004, while there has been more flexibility in the period 1995-99. As in China, a stable exchange rate has been valued as an external anchor for monetary policy in the wake of the 1990-1992 crisis and for its role in promoting trade and investment. Regarding the likely future evolution of the policy regime vis-à-vis the capital account and the exchange rate, Patnaik and Shah (2006a) highlight that the growth of current account flows has made capital controls easier to evade, through over/under invoicing and other mechanisms. The increase in de facto capital account openness means that there is increased potential for conflict between the pegged exchange rate regime and the needs of domestic monetary policy.

This gives rise to two possible scenarios according to Patnaik and Shah (2006a). The first is that India allows more flexibility in its currency. Monetary policy is thus partly recovered by giving up the peg and this also allows capital controls to be reduced even further, achieving eventually full capital account convertibility. The second scenario is that India stays with the peg, and there continues to be political tension between the sectors of the economy that want capital controls to be relaxed and the central bank that wants to pursue an independent monetary policy.

\section{AII.b.ii. The Domestic Financial System}

The financial sector in India was very underdeveloped at the end of the 1980s. The financial system was dominated by the state and closed to foreign influence (Thomas 2005). Most banks were state owned and had little equity capital. Banks, pension funds, and insurance companies were forced to buy government bonds as their primary investments. The Reserve Bank of India set interest rates on various products, and the ministry of finance controlled the price at which many securities were issued. There were many entry barriers in every area of financial industry, and foreign firms could not operate in any financial area. The balance of payments crisis of 1990 and the bond and stock market crises of 1991-92 highlighted the need for financial sector reform.

India undertook a reform of its financial institutions after the crisis. The Securities and Exchange Board of India was made operational in 1992 to reform the Bombay Stock Exchange (BSE) and other existing stock markets. Problems included archaic practices in trading, clearing, and settlement, described in further detail in Thomas (2005). However, these markets, which are independent, resisted reform. A new market, the National Stock Exchange (NSE) of India, was thus created in 1994. In this new market, orders were matched electronically and anonymously and there was equal access to all traders in a vast geographical area. In 1996, most of the trading in the BSE had been transferred to the NSE and the competition between exchanges prompted the rapid transformation of the BSE. There were also reforms in the banking sector, with the entry of private banks in the system, improved prudential norms, and an attempt to improve the autonomy of stateowned banks. ${ }^{53}$

\footnotetext{
${ }^{53}$ See Thomas (2005).
} 
As Figures 7, 8, and 9 illustrate, the domestic equity market is much more developed in relative terms than the banking sector or the bond market. It includes a private equity and venture capital industry for incubating firms, an IPO market, a liquid secondary market, stock market indexes and index funds, and equity derivatives. ${ }^{54}$ There has also been policy activism to improve corporate governance, thus encouraging investment by minority shareholders. ${ }^{55}$

The relative openness of equity markets has also improved liquidity. This has been a reinforcing process, since more liquidity has helped to attract more foreign investors, improving further the liquidity of the domestic market. Moreover, from 1995 onwards, the development of electronic trading in India improved the attractiveness of domestic trading compared to the trading of Indian equity abroad (through GDR/ADRs).

Finally, although the growth in the Indian equity market is impressive, Allen, Chakrabarti, De, Qian, and Qian (2006) raise some doubts about its overall contribution to capital formation. In particular, these authors highlight that equity issuance is a still a relatively minor source of investment finance, with bank lending and informal credit channels predominant, especially for smaller firms. In addition, these authors question the true effectiveness of shareholder protection, with corruption weakening the legal protection of investors in practice.

\footnotetext{
${ }^{54}$ See Shah (1995), Shah and Thomas (1998), Fernandes and Shah (2001), and Dossani and Kenney (2002).

${ }^{55}$ The Indian market's level of corporate governance scores well in the ranking of the CLSA Asia-Pacific Markets and Asian Corporate Governance Association.
} 
Figure 1

Net Foreign Asset Positions, 1985-2004

China and India

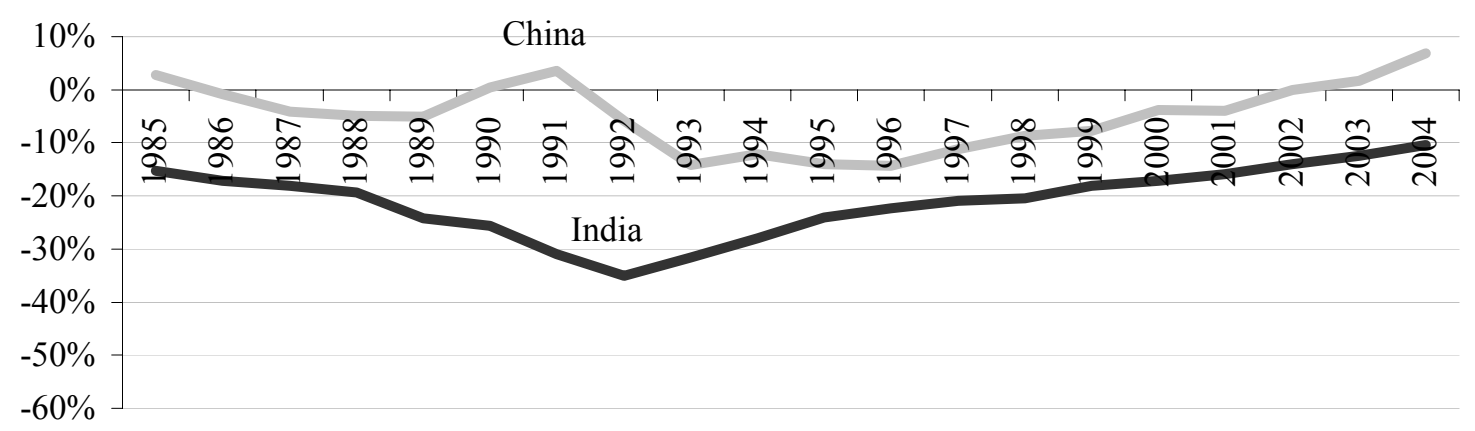

East Asia and G7

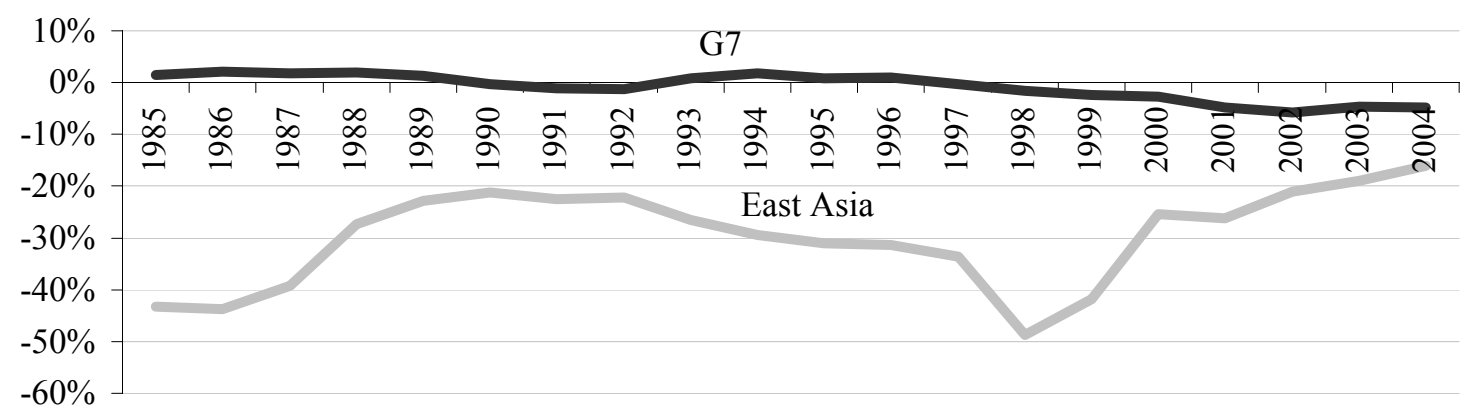

Eastern Europe and Latin America

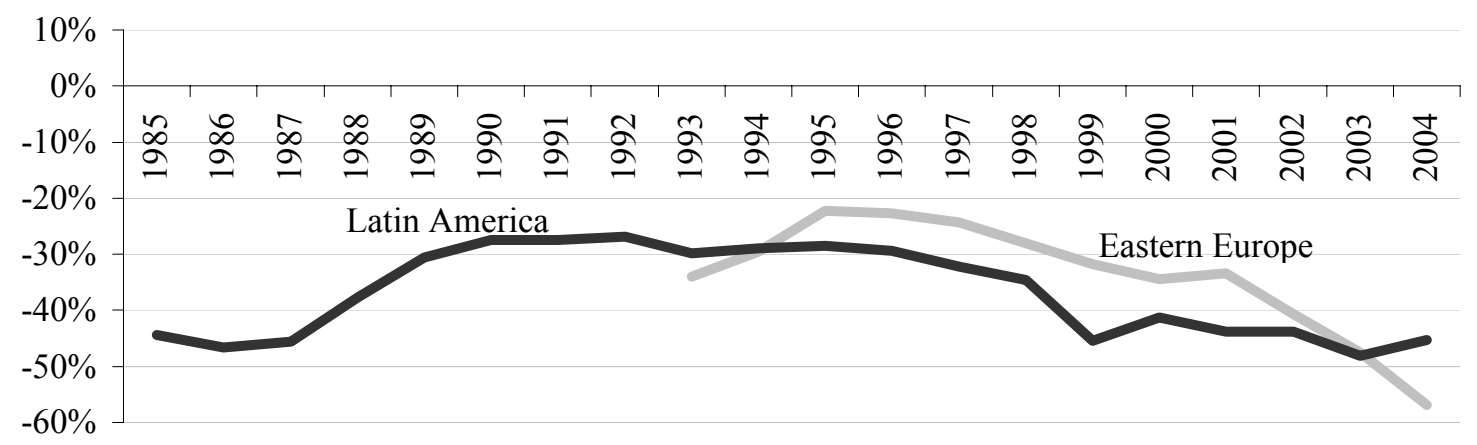

Net foreign asset position expressed as a ratio to GDP. East Asia is the average of Indonesia, Korea, Malaysia, and Thailand. G7 is the average of Canada, France, Germany, Italy, Japan, United Kingdom, and United States. Latin America is the average of Argentina, Brazil, Chile, and Mexico. Eastern Europe is the average of Czech Republic, Hungary, and Poland. The series for the regions are weighted averages where the weights are the countries' GDPs as a fraction of the region's GDP. Source: Authors' calculations drawing on the dataset constructed by Lane and Milesi-Ferretti (2006). 
Figure 2

Cross-section of Net Foreign Asset Postitions, 2004

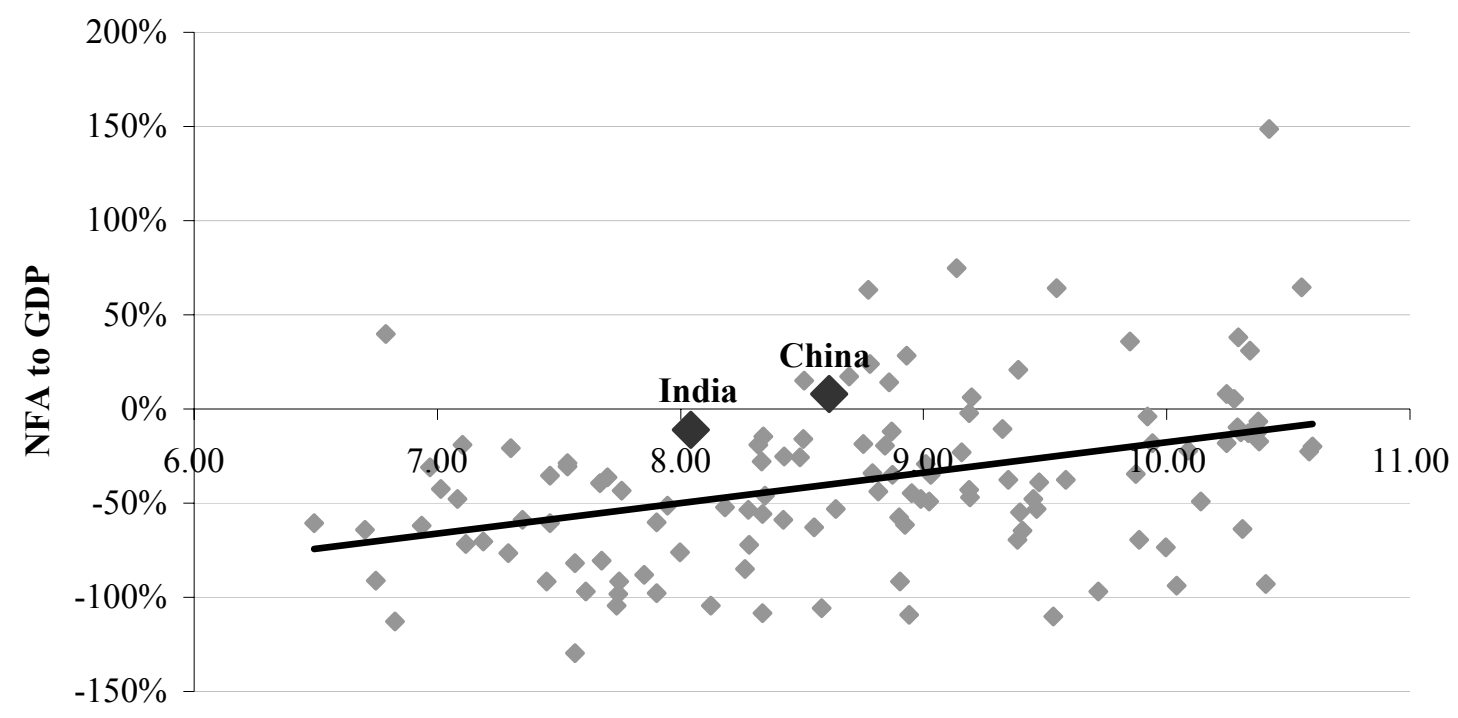

GDP per capita, PPP

Net foreign assets expressed as a ratio to GDP. Source: Lane (2006), drawing on the dataset constructed by Lane and Milesi-Ferretti (2006). 
Figure 3

International Financial Integration

China and India

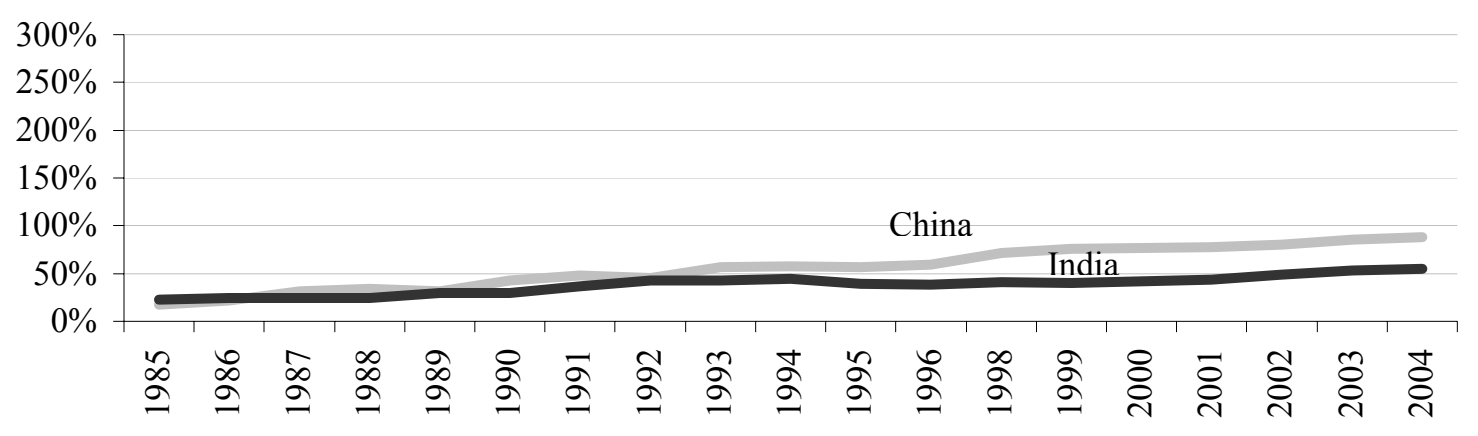

\section{East Asia and G7}

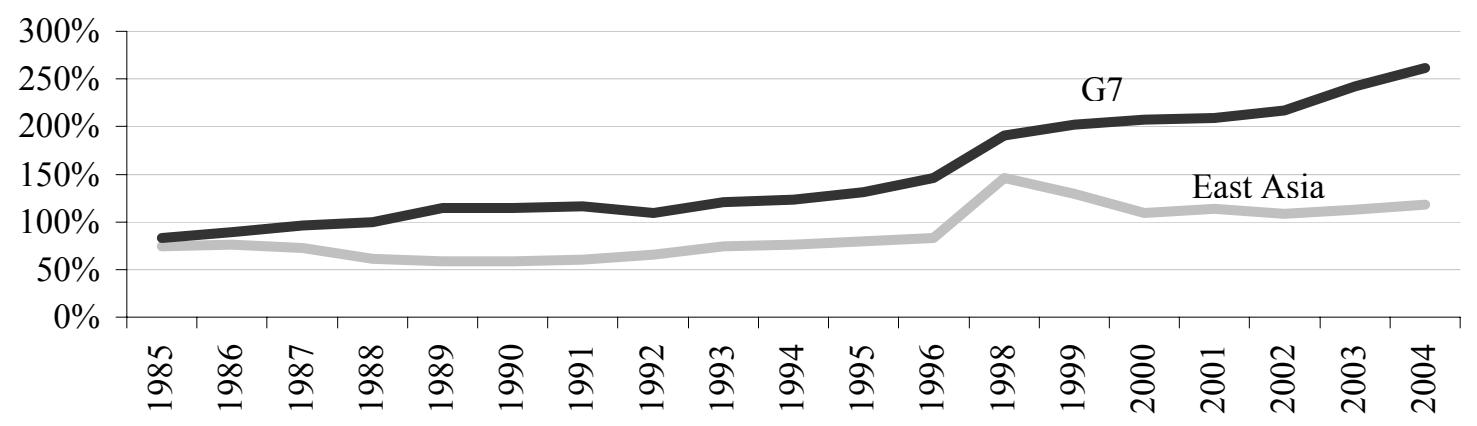

\section{Eastern Europe and Latin America}

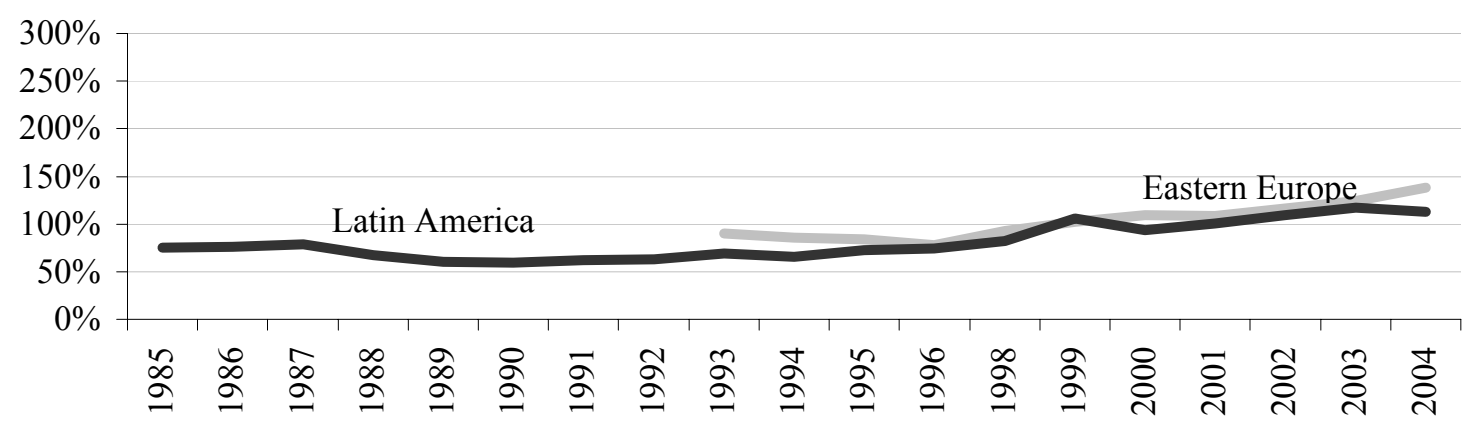

Sum of foreign assets and liabilities expressed as a ratio to GDP. East Asia is the average of Indonesia, Korea, Malaysia, and Thailand. G7 is the average of Canada, France, Germany, Italy, Japan, United Kingdom, and United States. Latin America is the average of Argentina, Brazil, Chile, and Mexico. Eastern Europe is the average of Czech Republic, Hungary, and Poland. The series for the regions are weighted averages where the weights are the countries' GDPs as a fraction of the region's GDP. Source: Authors' calculations drawing on the dataset constructed by Lane and Milesi-Ferretti (2006). 
Figure 4

World Shares of GDP, Trade, and International Financial Integration

\section{China}

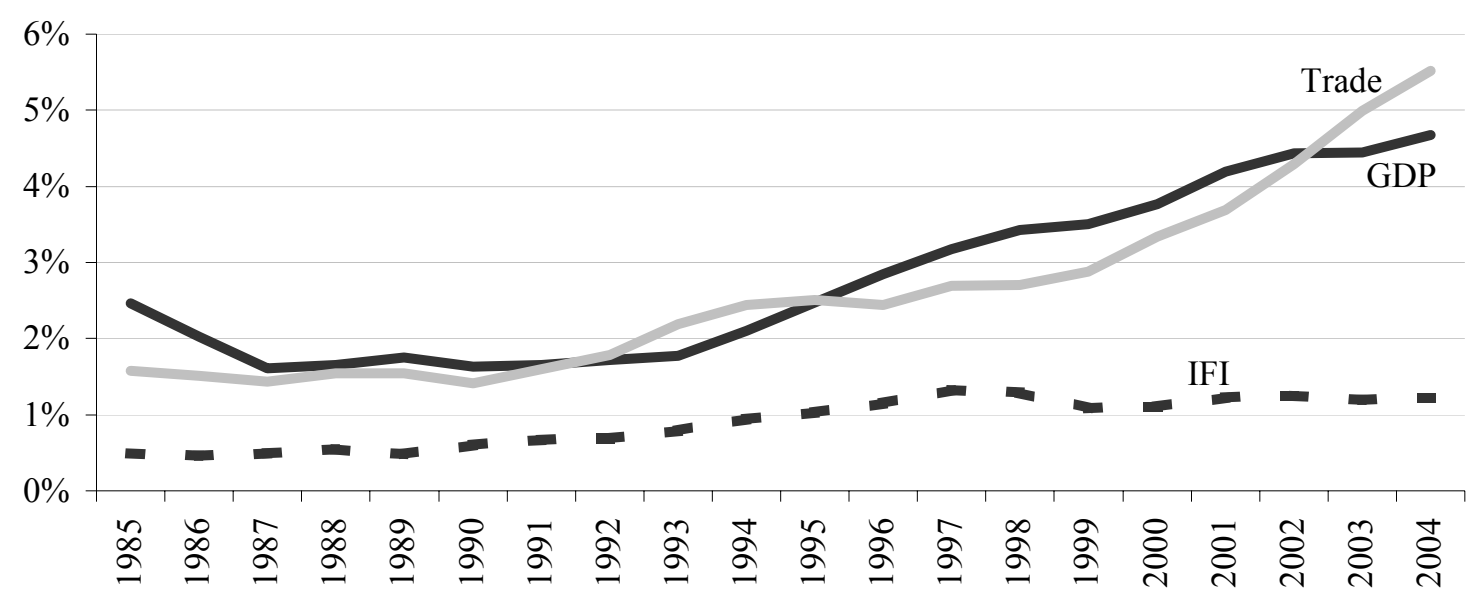

India

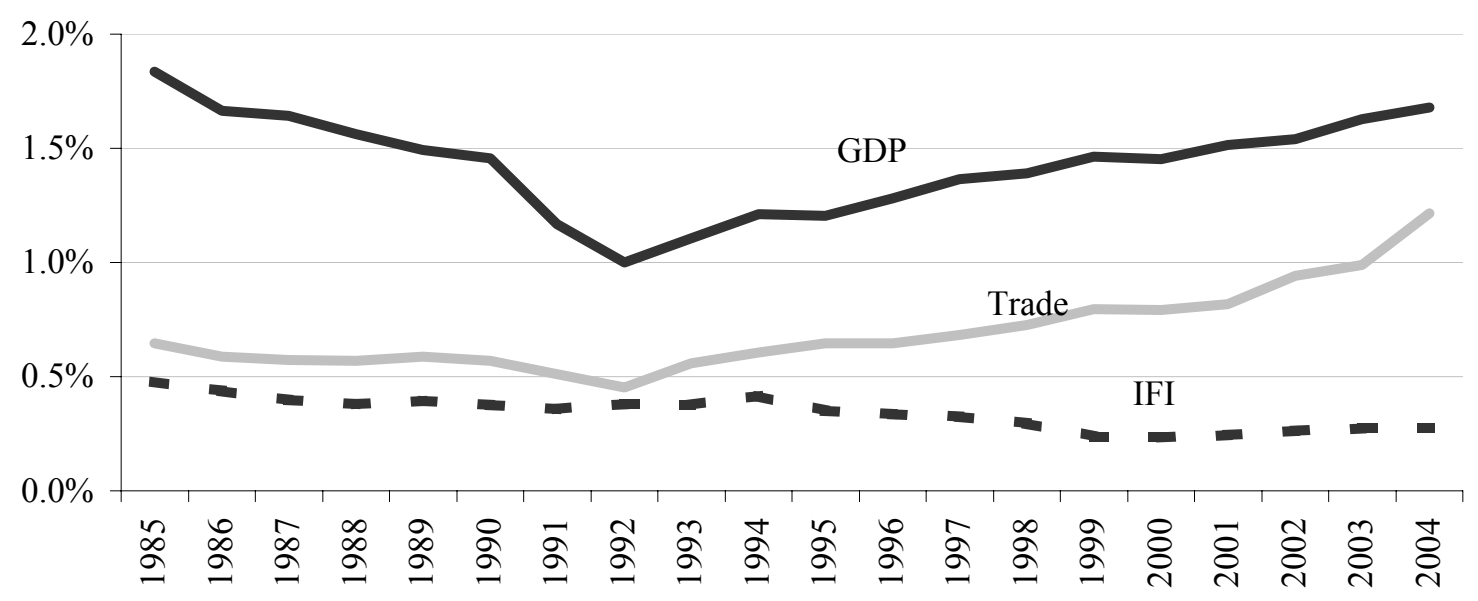

The GDP shares are calculated as the country's GDP divided by the sum of GDP for all the countries in the dataset. The trade shares are calculated as the country's exports plus imports divided by the sum of exports and imports of all the countries in the dataset. The international financial integration shares are calculated as the sum of the country's foreign assets plus foreign liabilities divided by the sum of these for all the countries in the dataset. Source: Authors' calculations drawing on the dataset constructed by Lane and Milsei-Ferretti (2006). 
Figure 5

Composition of Foreign Assets and Liabilities

Reserve and Non-Reserve Assets to GDP

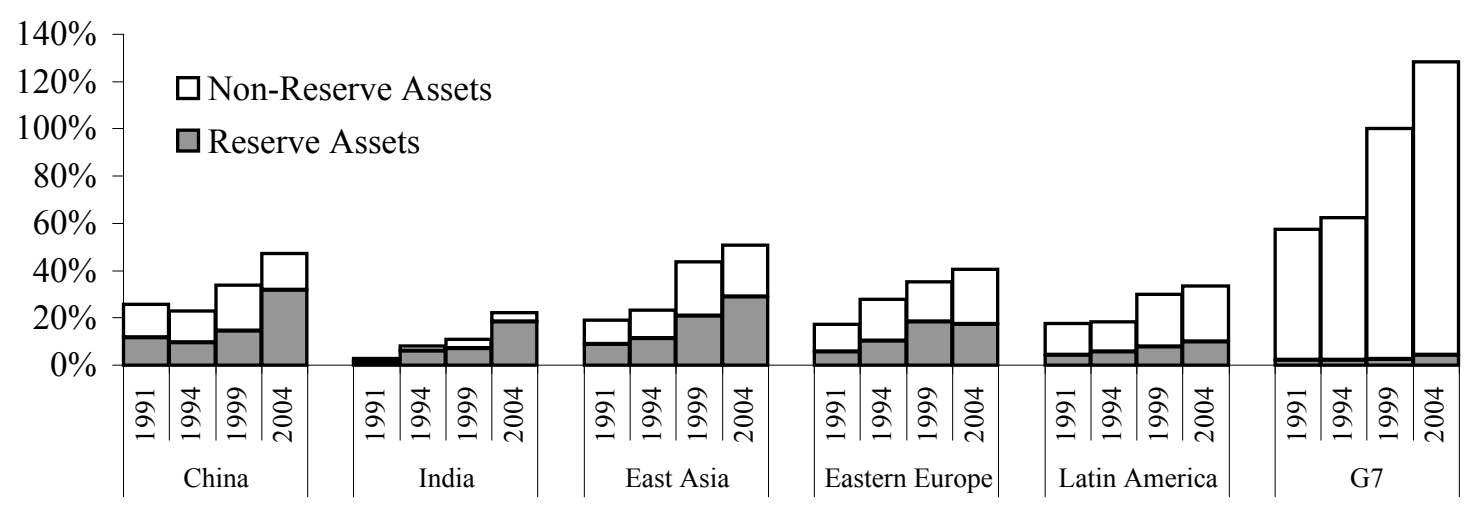

Debt and Equity Liabilities to GDP

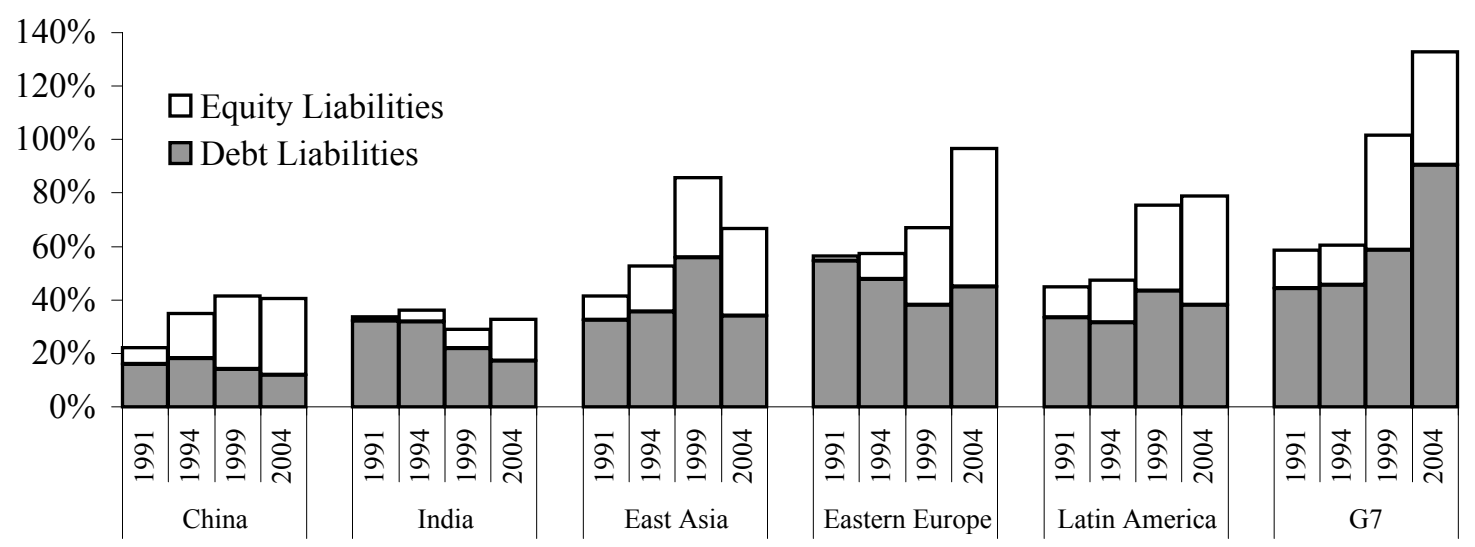

East Asia is the average of Indonesia, Korea, Malaysia, and Thailand. G7 is the average of Canada, France, Germany, Italy, Japan, United Kingdom, and United States. Latin America is the average of Argentina, Brazil, Chile, and Mexico. Eastern Europe is the average of Czech Republic, Hungary, and Poland. Source: Authors' calculations drawing on the dataset constructed by Lane and Milesi-Ferretti (2006). 
Figure 6

Top Foreign Asset and Liability Holders, 2004

Top Reserve Asset Holders

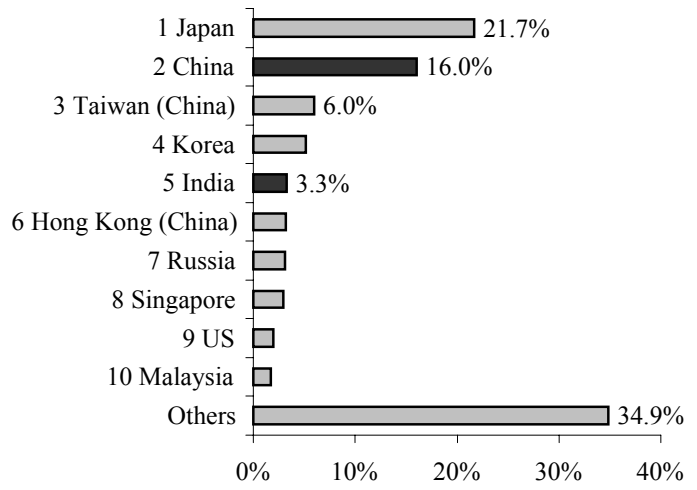

Top Portfolio Equity Liability Holders

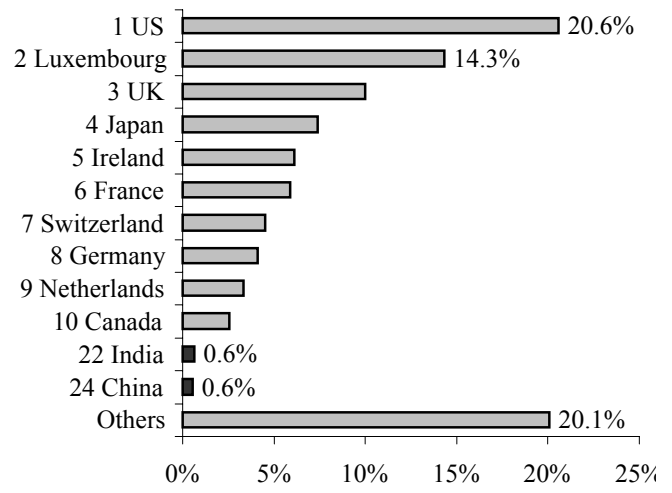

Top Debt Liability Holders

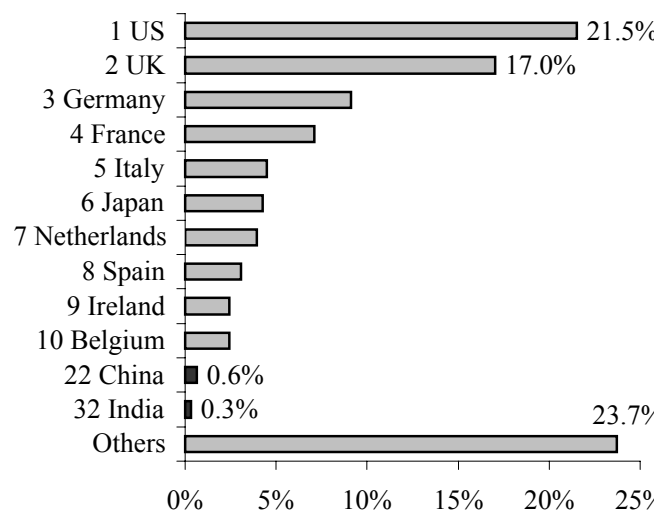

Top Non-Reserve Asset Holders

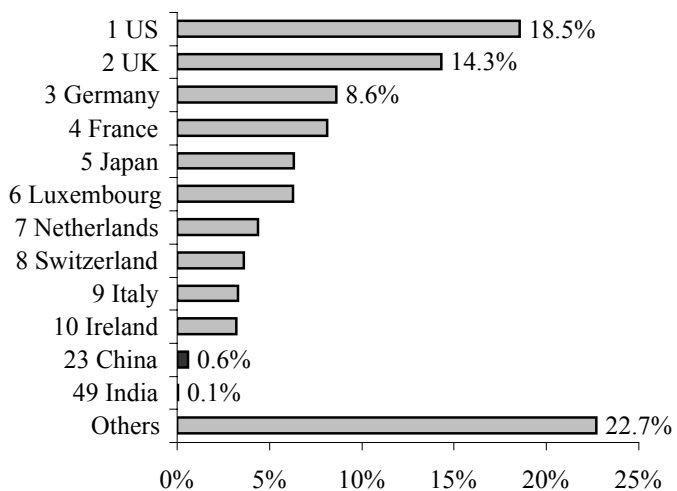

\section{Top FDI Liablity Holders}

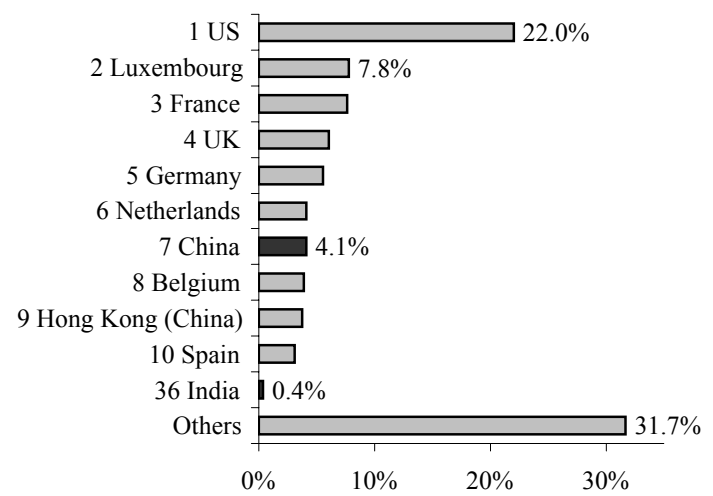

Share of World GDP

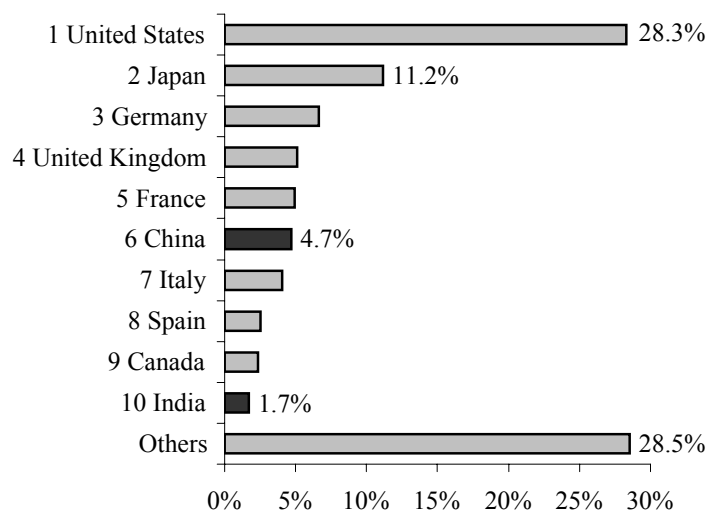

The figures show the holdings of foreign assets and liabilities, by type of asset and liability, of the ten largest holders, China, India, and the sum of all the other countries, as a percentage of total holdings of that type of asset or liability. It also shows the share of world GDP of the ten largest economies and India. Holdings are expressed as a percentage of the sum of the holdings of all the countries in the dataset. Numbers next to holdings show position in world ranking. Source: Authors' calculations drawing on the dataset constructed by Lane and Milesi-Ferretti (2006). 
Figure 7

Foreign Exchange Reserves and M1

Foreign Exchange Reserves to GDP

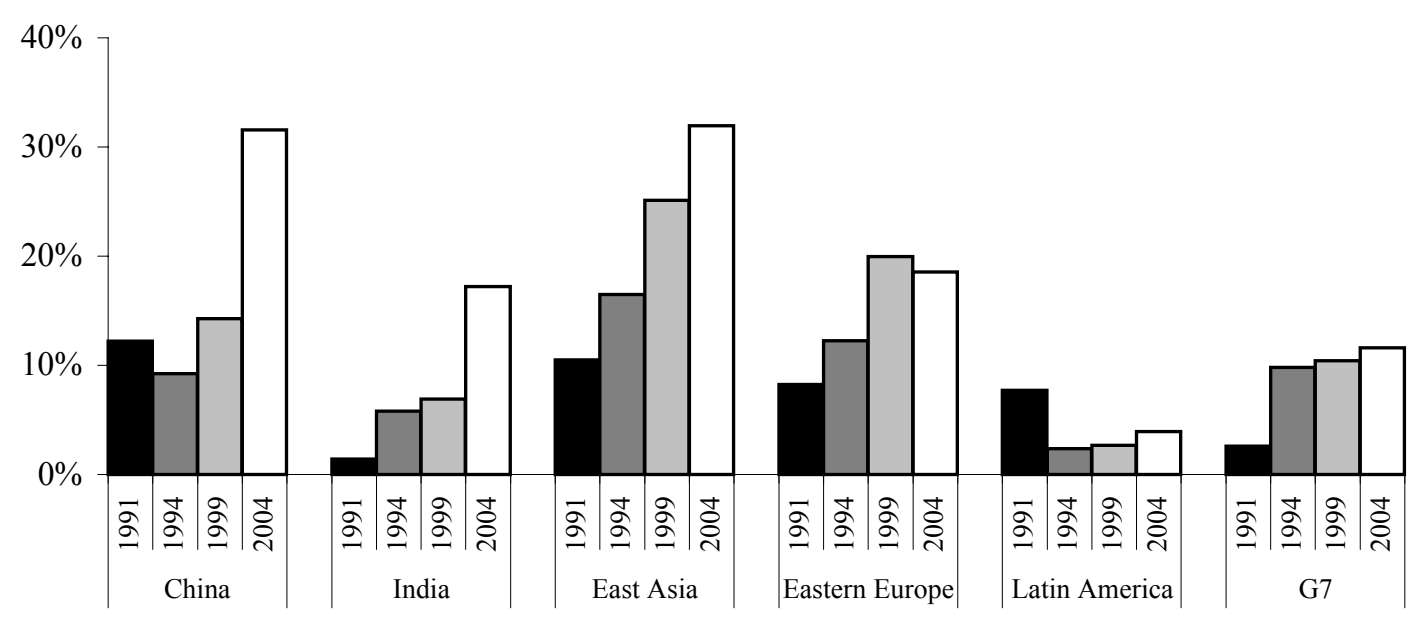

M1 to GDP

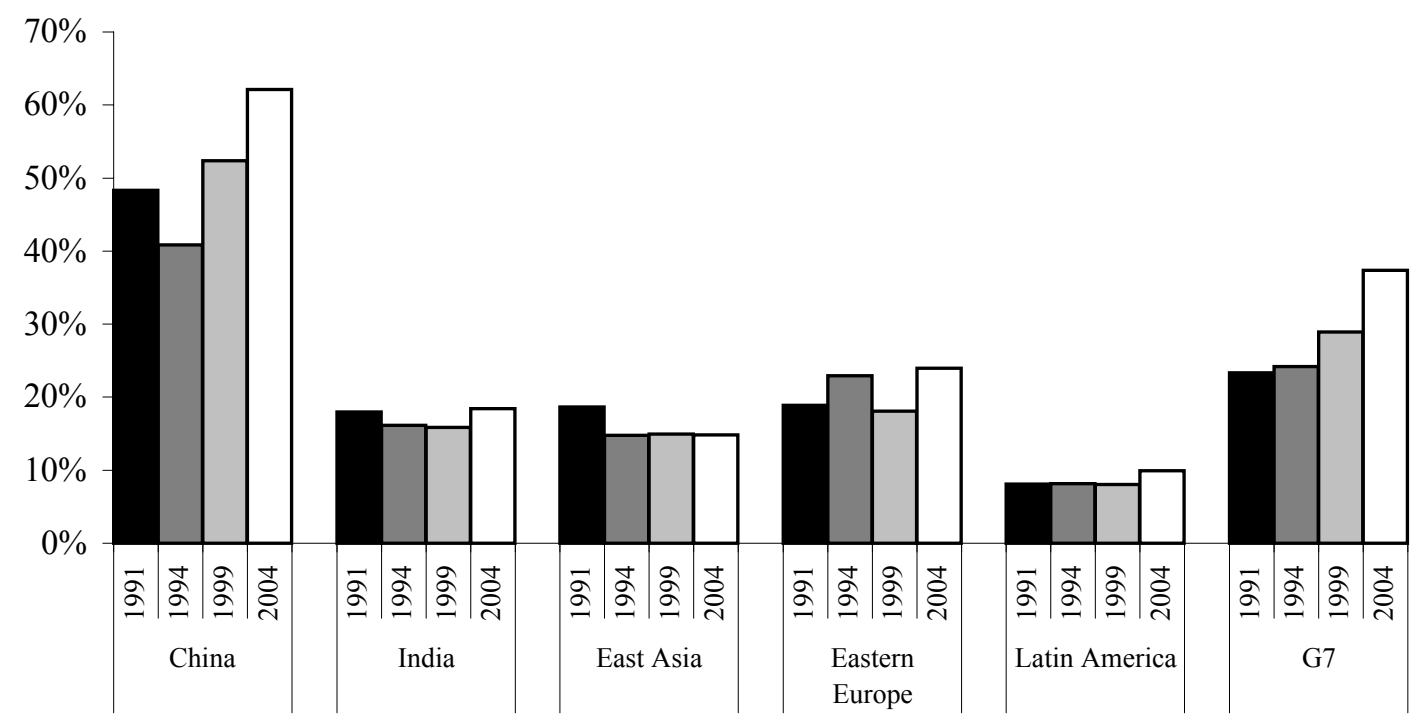

East Asia is the average of Indonesia, Korea, Malaysia, and Thailand. G7 is the average of Canada, France, Germany, Italy, Japan, United Kingdom, and United States. Latin America is the average of Argentina, Brazil, Chile, and Mexico. Eastern Europe is the average of Czech Republic, Hungary, and Poland. M1/GDP average for G7 does not include UK. Source: World Bank World Development Indicators and International Monetary Fund International Financial Statistics. 
Figure 8

Banking Sector

\section{Credit to GDP}

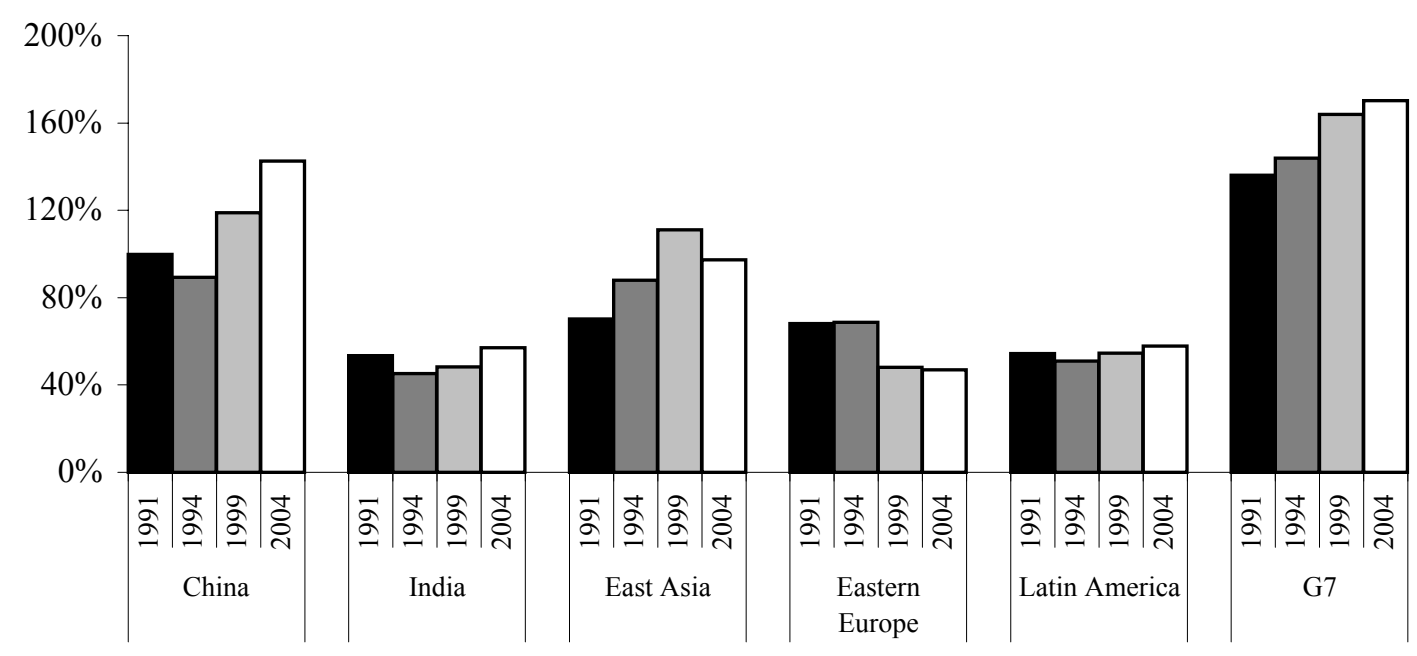

Deposits to GDP

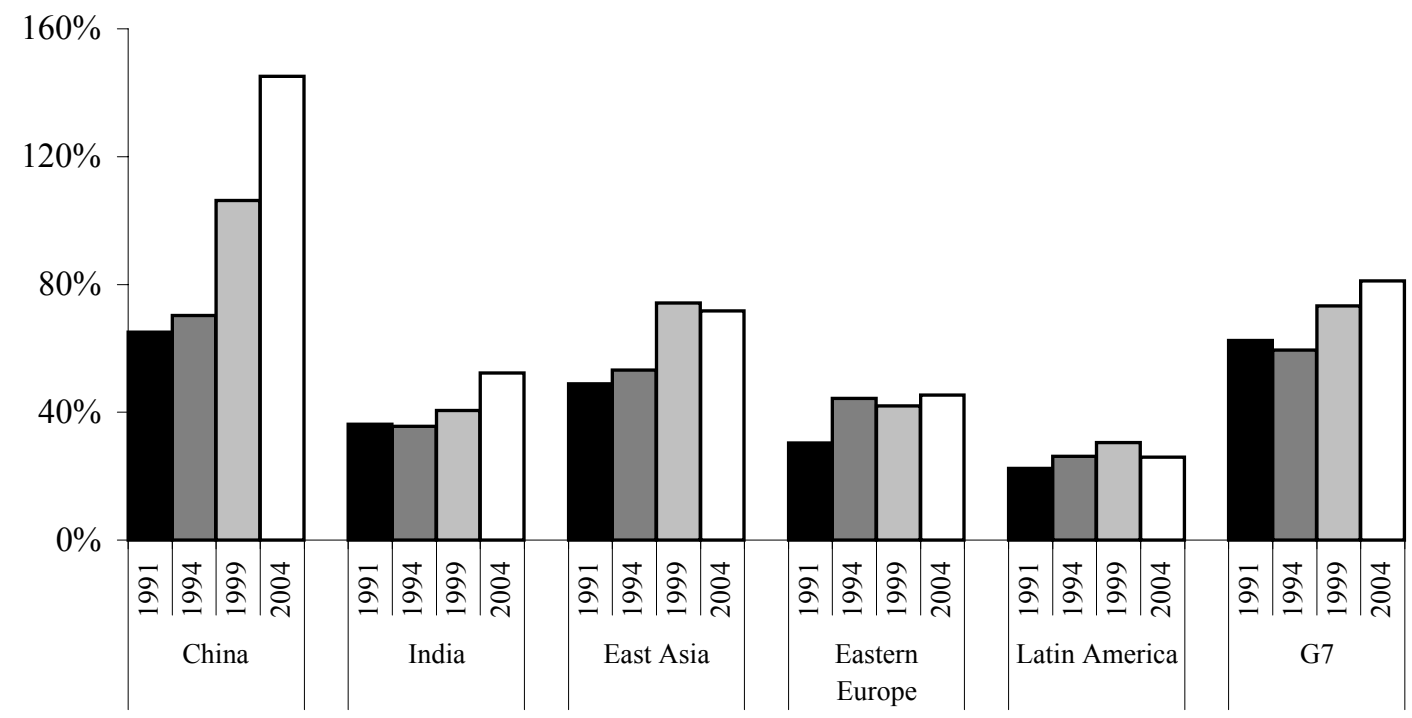

East Asia is the average of Indonesia, Korea, Malaysia, and Thailand. G7 is the average of Canada, France, Germany, Italy, Japan, United Kingdom, and United States. Latin America is the average of Argentina, Brazil, Chile, and Mexico. Eastern Europe is the average of Czech Republic, Hungary, and Poland. Source: World Bank World Development Indicators. The data source for Chinese deposits is Beck, Demirgüç-Kunt, and Levine (2006) for the years 1991, 1994, and 1999, and International Financial Statistics for 2004. 
Figure 9

Stock Markets

Number of Firms Listed

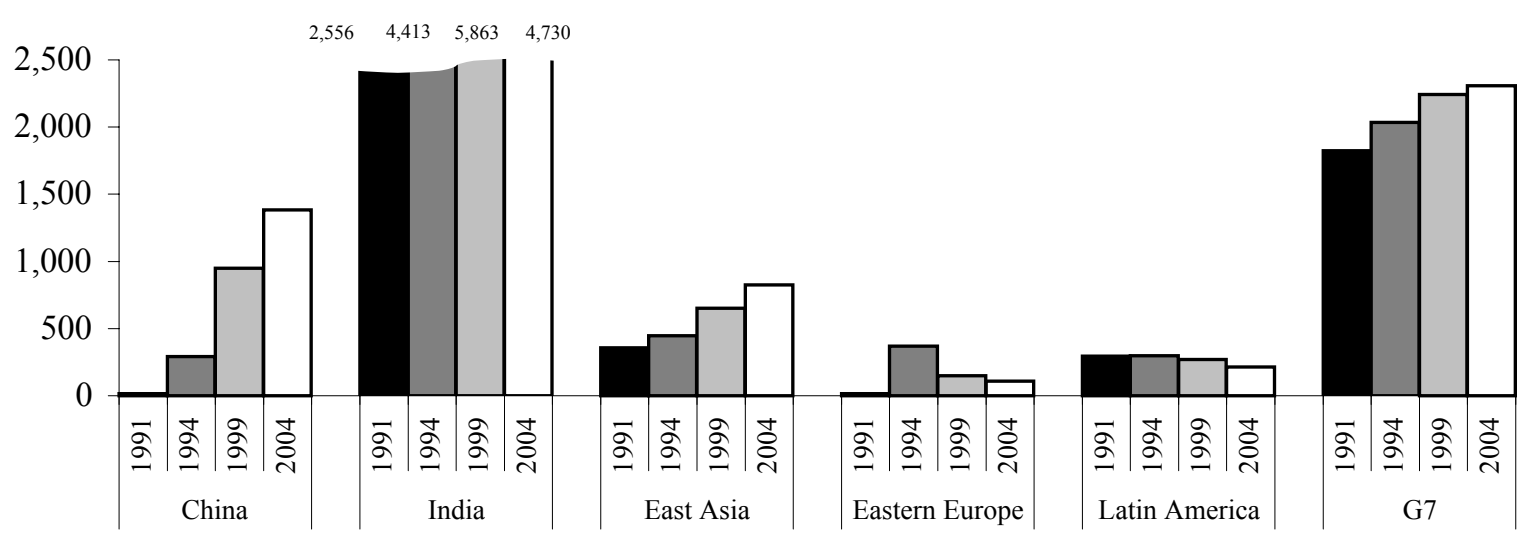

Market Capitalization to GDP

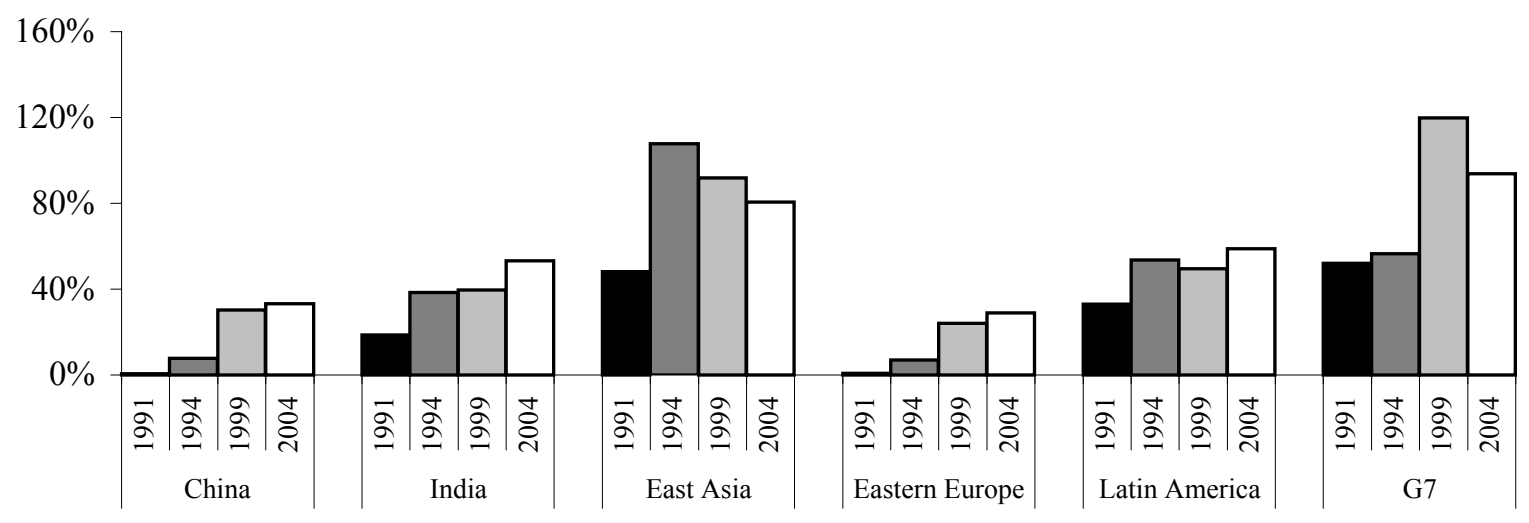

Turnover Ratio

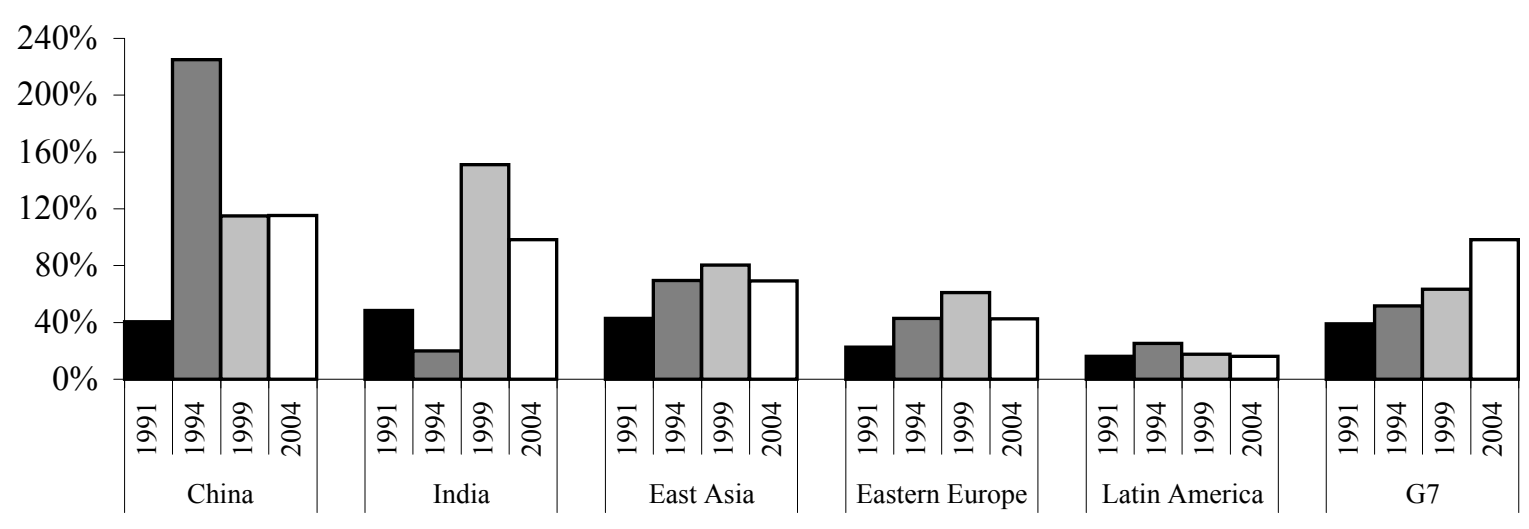

East Asia is the average of Indonesia, Korea, Malaysia, and Thailand. G7 is the average of Canada, France, Germany, Italy, Japan, United Kingdom, and United States. Latin America is the average of Argentina, Brazil, Chile, and Mexico. Eastern Europe is the average of Czech Republic, Hungary, and Poland. Source: Standard and Poor's Global Stock Markets Factbook and World Bank World Development Indicators. 
Figure 10

Debt Markets

\section{Private Bond Market Capitalization to GDP}

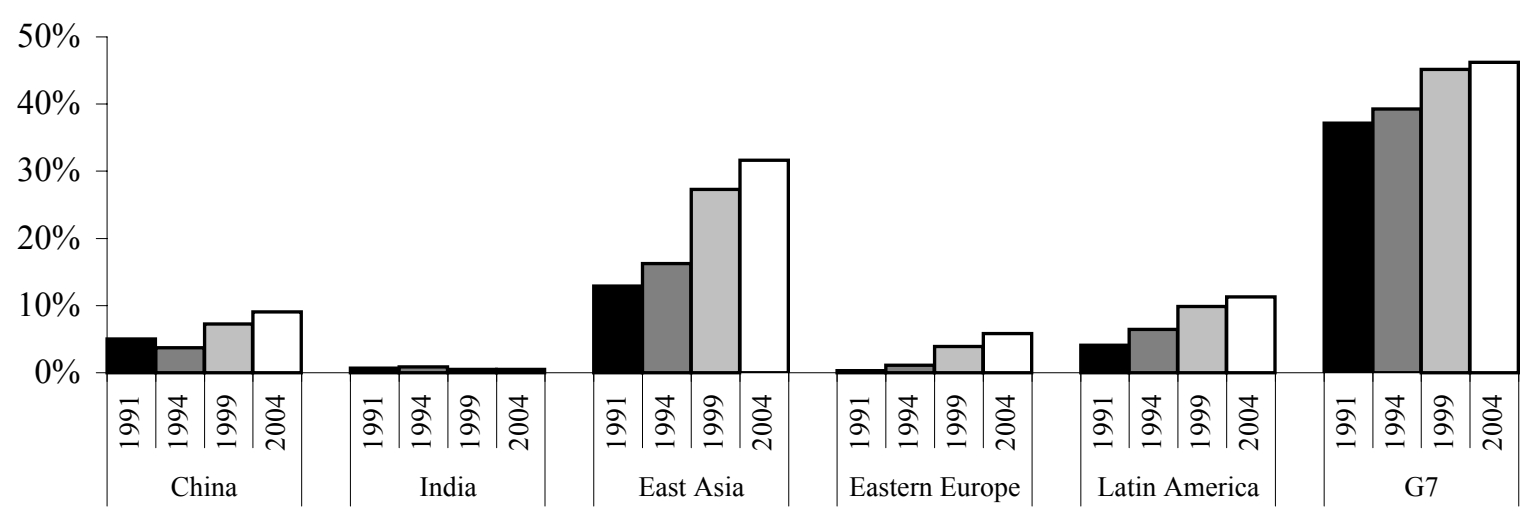

Public Bond Market Capitalization to GDP

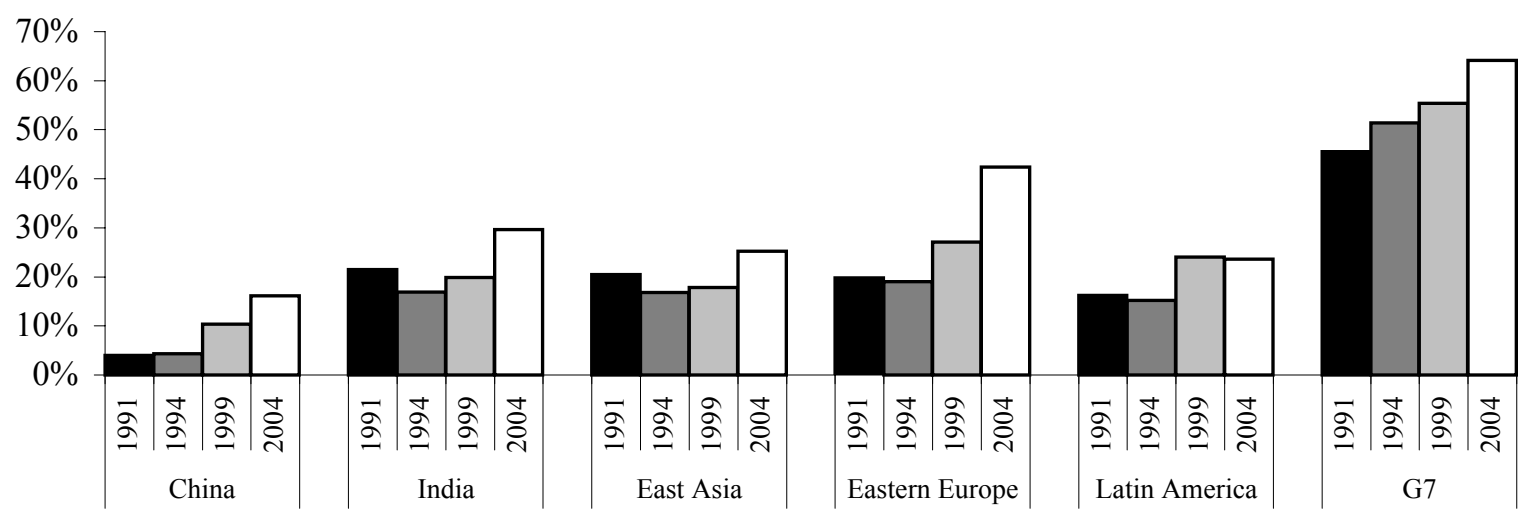

Central Government Debt to GDP

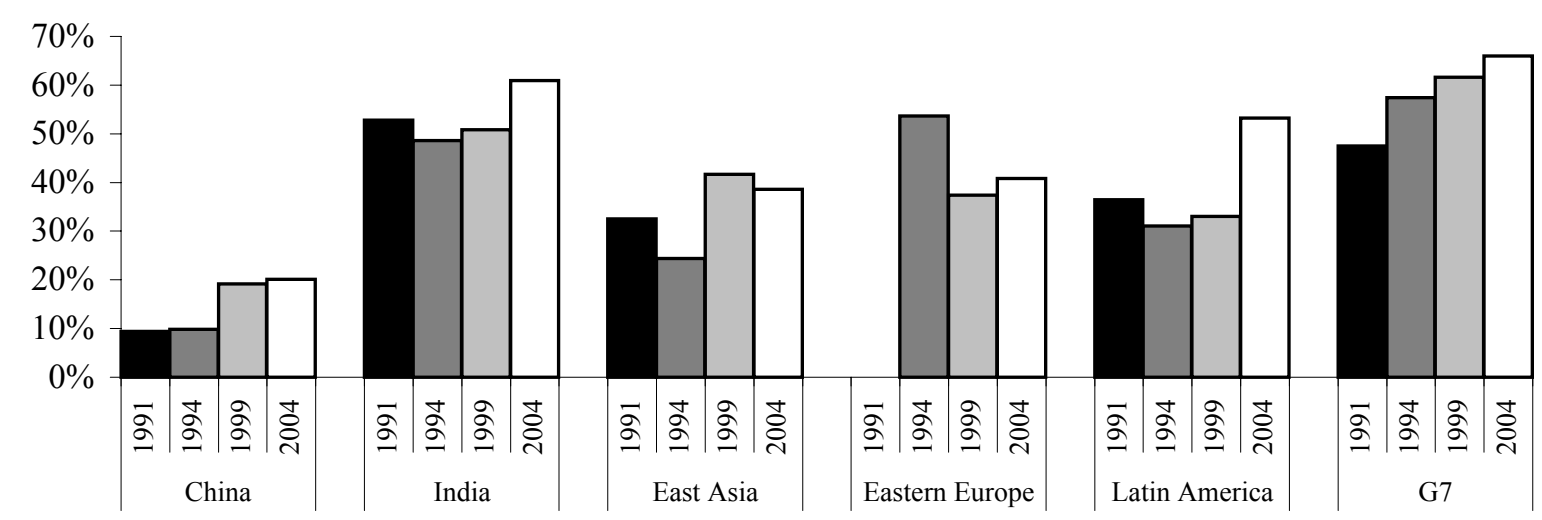

East Asia is the average of Indonesia, Korea, Malaysia, and Thailand. G7 is the average of Canada, France, Germany, Italy, Japan, United Kingdom, and United States. Latin America is the average of Argentina, Brazil, Chile, and Mexico. Eastern Europe is the average of Czech Republic, Hungary, and Poland. Source: Beck, Demirgüç-Kunt and Levine (2006), and Jaimovich and Panizza (2006). 
Table 1

Major Creditors and Debtors, 2004

\begin{tabular}{|c|c|c|c|}
\hline Country & NFA / World GDP & Country & NFA / World GDP \\
\hline 1 Japan & 4.34 & 1 United States & -6.49 \\
\hline 2 Switzerland & 1.25 & 2 Spain & -1.19 \\
\hline 3 Taiwan (China) & 1.06 & 3 Australia & -0.96 \\
\hline 4 Hong Kong (China) & 1.05 & 4 Italy & -0.75 \\
\hline 5 United Arab Emirates & 0.54 & 5 Brazil & -0.72 \\
\hline 6 Germany & 0.54 & 6 Mexico & -0.71 \\
\hline 7 Singapore & 0.46 & 7 United Kingdom & -0.67 \\
\hline 8 Norway & 0.40 & 8 Greece & -0.37 \\
\hline 9 Saudi Arabia & 0.39 & 9 Turkey & -0.33 \\
\hline 10 China & 0.32 & 10 Poland & -0.32 \\
\hline 11 Kuwait & 0.31 & 11 Canada & -0.30 \\
\hline 12 France & 0.27 & 12 Indonesia & -0.29 \\
\hline 13Belgium & 0.27 & 13 Portugal & -0.28 \\
\hline 14 Libya & 0.16 & 14 Hungary & -0.24 \\
\hline 15 Qatar & 0.15 & 15 New Zealand & -0.22 \\
\hline 16 Iran, Islamic Republic & 0.12 & 16 India & -0.18 \\
\hline 17 Luxembourg & 0.09 & 17 Argentina & -0.18 \\
\hline
\end{tabular}

Net foreign assets divided by world GDP. Numbers next to countries show position in world ranking. Source: Author's calculations based on dataset of Lane and Milesi-Ferretti (2006). 
Table 2a

Composition of Foreign Assets and Liabilities, 2004

\begin{tabular}{|c|c|c|c|c|}
\hline & \multicolumn{2}{|c|}{ China } & \multicolumn{2}{|c|}{ India } \\
\hline & Assets & Liabilities & Assets & Liabilities \\
\hline Portfolio Equity & 0.3 & 2.9 & 0.1 & 9.1 \\
\hline FDI & 1.9 & 25.7 & 1.3 & 6.4 \\
\hline Private Debt & 13.3 & 11.9 & 2.6 & 17.0 \\
\hline Reserves & 31.8 & & 18.3 & \\
\hline Total & 47.3 & 40.5 & 22.3 & 32.6 \\
\hline
\end{tabular}

Variables are expressed as a percentage of GDP. Source: Authors' calculations, based on dataset constructed by Lane and Milesi-Ferretti (2006).

Table 2b

Asymmetries in the International Balance Sheet, 2004

\begin{tabular}{lrr}
\hline & China & India \\
\cline { 2 - 3 } Net Portfolio Equity & -2.6 & -9.0 \\
Net FDI & -23.8 & -5.0 \\
Net Equity & $\mathbf{- 2 6 . 5}$ & $-\mathbf{1 4 . 1}$ \\
Net Private Debt & 1.5 & -14.6 \\
Reserves & 31.8 & 18.3 \\
Net Debt & $\mathbf{3 3 . 3}$ & $\mathbf{3 . 7}$ \\
& & \\
\hline Variables are expressed as a percentage of GDP. Net Private Debt equals non-reserve debt assets \\
minus debt liabilities. Source: Authors' calculations, based on dataset constructed by Lane and \\
Milesi-Ferretti (2006).
\end{tabular}


Table 3a

Sources of FDI Liabilities, 2004

\begin{tabular}{lclc}
\hline & \multicolumn{2}{c}{ China } & India \\
\cline { 2 - 2 } World & \multirow{2}{*}{ Hong Kong (China) } & World & 100.0 \\
Hong & 45.0 & Mauritius & 35.6 \\
United States & 8.9 & United States & 16.5 \\
Japan & 8.7 & Japan & 6.9 \\
Taiwan (China) & 7.4 & Netherlands & 6.9 \\
British Virgin Islands & 6.9 & UK & 6.6 \\
Korea & 4.8 & Germany & 4.4 \\
Singapore & 4.8 & Singapore & 3.1 \\
United Kingdom & 2.3 & France & 2.7 \\
Germany & 1.8 & Korea & 2.2 \\
France & 1.3 & Switzerland & 2.0 \\
Other & 8.2 & Other & 13.2 \\
\hline Distribution by country of origin of China's and India's FDI liabilities. Figures show percent of liabilities \\
from each source country. Source: Authors' calculations based on data from the Chinese Ministry of \\
Commerce of the People's Republic of China (http://www.fdi.gov.cn) and the Indian Department of Industrial \\
Policy and Promotion (http://dipp.nic.in/).
\end{tabular}

Table 3b

Sources of Portfolio Liabilities, 2004

\begin{tabular}{|c|c|c|c|c|c|}
\hline & & & & & \\
\hline & Equity & Debt & & Equity & Debt \\
\hline World & 100.0 & 100.0 & World & 100.0 & 100.0 \\
\hline Hong Kong (China) & 34.3 & 36.7 & United States & 41.2 & 13.4 \\
\hline United States & 28.6 & 16.3 & Mauritius & 31.5 & 27.8 \\
\hline Europe 15 & 24.7 & 20.4 & Europe 15 & 24.1 & 22.8 \\
\hline Japan & 4.6 & 10.3 & Japan & 0.2 & 11.9 \\
\hline Singapore & 3.9 & 10.3 & Singapore & 0.4 & 16.6 \\
\hline Other & 4.0 & 5.9 & Other & 2.6 & 7.6 \\
\hline
\end{tabular}

Distribution by country of origin of China's and India's portfolio liabilities. Figures show percent of liabilities from each source country. Source: Authors' calculations based on data from Coordinated Portfolio Investment Survey. 


\section{Table 4}

Brief Chronology of China's Financial Liberalization Since 1990

1990 Shanghai Securities Exchange was officially recognized.

April 1990 An amendment to the law on Chinese foreign equity joint ventures, stipulating that the State would not nationalize joint ventures, simplifying the approval procedures for new foreign investment enterprises, and extending the management rights of foreigners was passed.

May 1990 Shanghai was opened to FDI, with tax incentives similar to special economic zones.

The State Council issued regulations for the sale and transfer of land use rights in cities and towns to encourage foreign investors to plan long-term investment.

1991 Shenzhen Stock Exchange was officially recognized.

April 1991 The tax of ten percent on distributed profits remitted abroad by foreign investors in foreign funded enterprises was eliminated, unifying the tax rates on Chinese foreign joint ventures and entirely foreign enterpises. Also, more tax benefits were given to priority industrial sectors.

1992 The B-share market was launched.

March 1992 Foreign investment was further liberalized, with the opening of a large number of in-land and border areas.

July 1993 Qingdao Beer was the first Chinese firm to list in the Hong Kong Stock Exchange.

1997 Financial institutions were allowed to issue bonds in international markets with SAFE approval.

February 1999 A private Chinese firm was listed abroad for the first time.

February 2001 Domestic investors were allowed to purchase B shares with existing foreign currency deposits.

June 2001 Domestic investors were allowed to purchase B shares with new foreign currency deposits.

September 2001 Restrictions were liberalized on purchases of foreign exchange for advance repayments of loans and debts.

April 2002 A new four-tier classification was introduced, defining sectors in which foreign investment is encouraged, permitted, restricted, or banned. As a result, sectors that were previously closed to foreign investment were opened.

December 2002 Qualified foreign institutional investors were allowed to purchase A shares, subject to restrictions.

January 2003 Permission from the SAFE was no longer required for domestic residents to borrow foreign exchange from domestic Chinese financial institutions.

November 2003 In some provinces and regions, the limit on outward direct investment was raised to $\$ 3$ million, from $\$ 1$ million.

2004 Insurance companies were allowed to use their own foreign exchange to invest in international capital markets.

January 2004 The asset requirements for Hong Kong (China) banks to open branches in mainland China were lowered to $\$ 6$ billion, from $\$ 20$ billion. Other restrictions on Hong Kong banks were eased too.

June 2004 Domestic foreign-funded banks were not permitted to convert debt contracted abroad into RMB, and were not allowed to purchase foreign exchange for servicing such debts.

Capital remitted through FDI could only be converted to RMB upon proof of domestic payment

December 2004 Foreign heirs were allowed to take inheritance out of the mainland. Emigrants were allowed to take legally obtained personal assets with them.

2005 A foreign company was listed in the Shanghai Stock Exchange for the first time.

February 2005 Domestic residents were allowed to set up companies abroad to facilitate round-tripping investment or overseas financing (issuing bonds and stocks). This made it easier for private firms to access international capital markets and for foreign investment banks/funds to provide financial services to Chinese firms.

April 2006 The People's Bank of China announced the qualified domestic institutional investor (QDII) program, under which mainland Chinese financial institutions are allowed to invest in offshore securities. It stipulated that: i) qualified banks may assemble the funds in domestic currency from domestic institutions and individuals and invest these funds in fixed income products in international market, ii) qualified security firms may assemble funds from institutions and individuals and invest in international capital market including stocks, and iii) insurance companies may invest in foreign fixed income and monetary instruments.

Source: Prasad and Wei (2005) and Zhao (2006). 
Table 5

Brief Chronology of India's Financial Liberalization Since 1990

July 1991 The government abolished the industrial licensing system, except in 15 critical industries, and reduced the number of industries reserved to the public sector from 17 to 6 . Government approval for the expansion of large firms was no longer necessary, including foreign firms. Foreign firms were allowed major shareholding in joint-ventures, and foreign investment up to 51 percent of equity in 35 priority industries received automatic approval. The new investment policy also spelled more incentives to attract FDI from non-resident Indians, including 100 percent ownership share in many sectors and full repatriation of profits.

1992 The Security and Exchange Board of India (SEBI) Act was passed: the SEBI became operational as an independent regulator.

Septmeber 1992 Foreign institutional investors (FIIs) were given permission to participate in the Indian market. One FII could own up to five percent of a firm, and all FIIs combined could own 24 percent. A minimum of 70 percent investment in equities was required. FIIs had to have at least 50 investors.

1994 The National Stock Exchange (NSE) began trading bonds in June, and equity in November. Differentiating features of the NSE included: equal access to all traders in a vast geographical area, a competitive market in security intermediation, electronic matching of trades on the basis of price-time priority, anonymous trading followed by guaranteed settlement, and a more independent corporte governance structure (not an association of brokers).

November 1996 "One hundred percent debt FIIs" were permitted. These were allowed to buy corporate bonds, but not government bonds.

April 1997 The ceiling upon total ownership by all FIIs of a firm was raised from 24 percent to 30 percent. A shareholder resolution was required.

April 1998 FIIs were permitted to invest in government bonds, with a ceiling upon all FIIs put together of $\$ 1$ billion.

June 1998 The ceiling upon ownership by one FII in one firm was raised from five percent to ten percent. FIIs were permitted to partially hedge currency exposure risk using the forward market. FIIs were permitted to trade equity derivatives in a limited way.

August 1999 The requirement that FIIs must have at least 50 investors was eased to 20 investors.

February 2000 Foreign firms and individuals were permitted access to the Indian market through FIIs as "subaccounts." Local fund managers were also permitted to do fund management for foreign firms and individuals through subaccounts. The requirement that no investor was allowed to have more than five percent of an FII was eased to ten percent.

March 2000 The ceiling upon total ownership by all FIIs of a firm was raised from 30 percent to 40 percent. A shareholder resolution was required.

March 2001 The ceiling upon total ownership by all FIIs of a firm was raised from 40 percent to 49 percent. A shareholder resolution was required.

September 2001 The ceiling upon total ownership by all FIIs of a firm was raised from 49 percent to "the sectoral cap for the industry". A shareholder resolution was required.

January 2003 Limitations upon FIIs hedging using the forward currency market were removed.

December 2003 Twin approvals for FIIs at both SEBI and RBI were replaced by single approval at SEBI.

November 2004 A new ceiling upon total ownership by all FIIs of corporate bonds was placed at $\$ 0.5$ billion.

February 2006 The ceiling upon ownership of government bonds by all FIIs was raised to \$2 billion, and the ceiling upon ownership of corporate bonds by all FIIs was raised to $\$ 1.5$ billion.

Source: Patnaik and Shah (2006b), Sharma (2000), and Thomas (2005). 